\title{
Review \\ Urinary analysis of nephrolithiasis markers
}

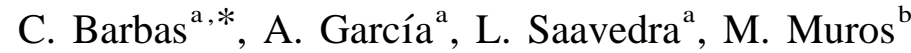 \\ ${ }^{\text {a } F a c u l t a d ~ d e ~ C C ~ E x p e r i m e n t a l e s ~ y ~ d e ~ l a ~ S a l u d, ~ U n i v e r s i d a d ~ S a n ~ P a b l o-C E U, ~ U r b a n i z a c i o ́ n ~ M o n t e p r i ́ n c i p e, ~ C t r a . ~ B o a d i l l a ~ d e l ~ M o n t e, ~}$ \\ km 5,3, 28668 Madrid, Spain \\ ${ }^{\mathrm{b}}$ Servicio de Análisis Clínicos, Hospital Virgen de Candelaria, Carretera del Rosario, s/n 38010, Santa Cruz de Tenerife, Spain
}

\begin{abstract}
Renal stone disease is an ancient and common affliction, common in industrialised nations. The causes and incidence of nephrolithiasis are presented. Afterwards, the promoters and inhibitors of renal stone formation analysis in urine are described including enzymatic methods, chromatography, capillary electrophoresis and other techniques. Aspects such as sample collection and storage are also included. The review article includes referenced tables that provide summaries of methodology for the analysis of nephrolithiasis related compounds.
\end{abstract}

(C) 2002 Elsevier Science B.V. All rights reserved.

Keywords: Reviews; Renal stones; Oxalate; Citrate

\section{Contents}

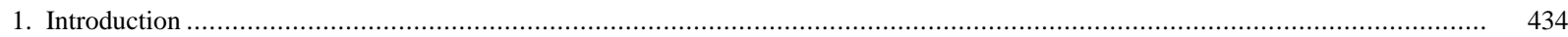

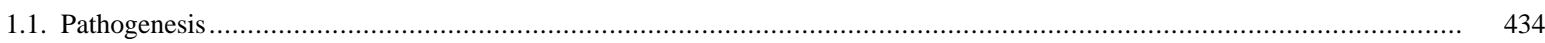

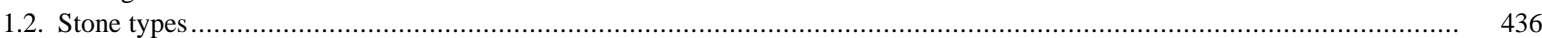

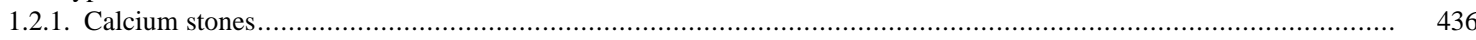

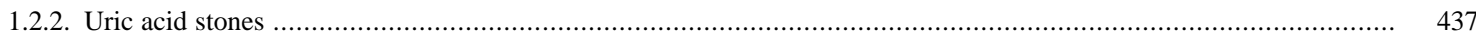

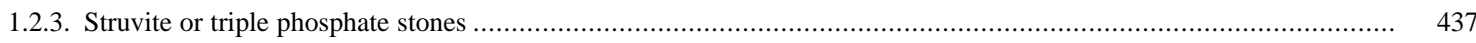

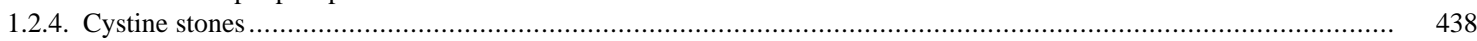

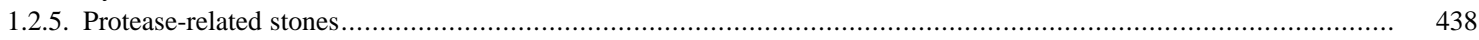

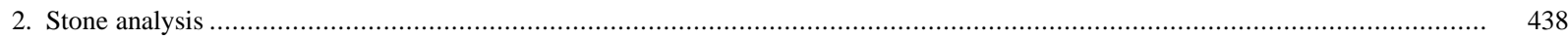

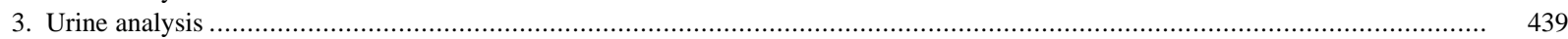

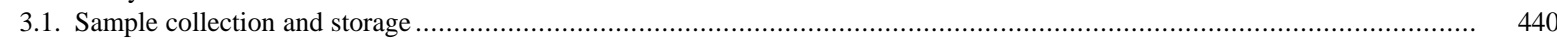

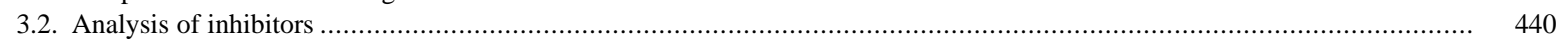

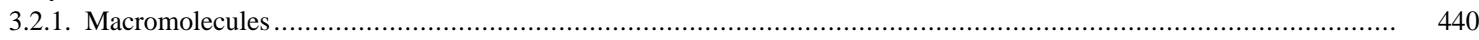

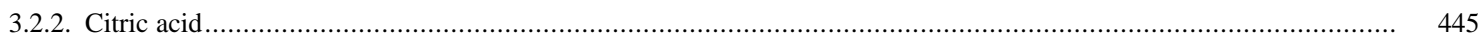

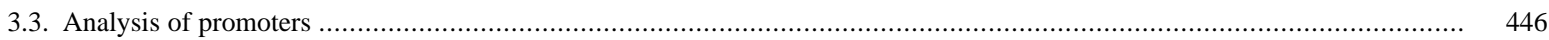

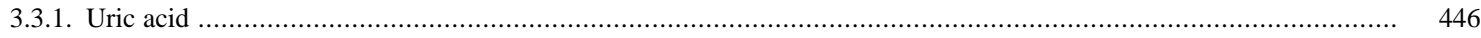

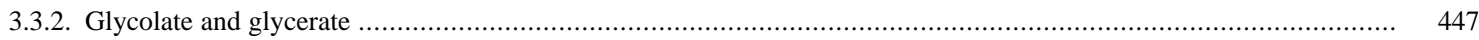

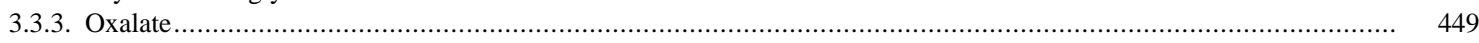

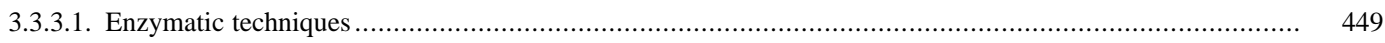

*Corresponding author. Fax: +34-91-351-0475.

E-mail address: cbarbas@ceu.es (C. Barbas).

1570-0232/02/\$ - see front matter (C) 2002 Elsevier Science B.V. All rights reserved. 


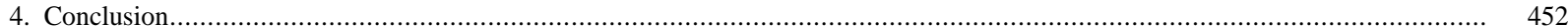

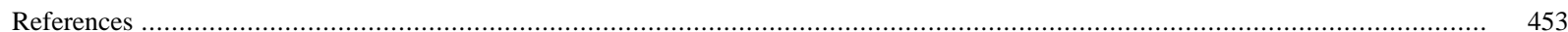

\section{Introduction}

Renal stone disease is an ancient and common affliction, whose clinical occurrence and presentation are described in the Aphorisms of Hippocrates [1]. The earliest recorded example of urinary stones are bladder and kidney stones detected in Egyptian mummies dated to 4800 B.C. Kidney stones are aggregates of crystals mixed with a protein matrix that cause obstruction of urine flow in the renal collecting system, ureters, or urethra and result in severe pain, bleeding or local erosion of kidney tissue.

Kidney stones are common in industrialised nations: up to $15 \%$ of white men and $6 \%$ of all women will develop one stone, with recurrence in about half these people. It has been estimated that seven to ten of every 1000 hospital admissions are due to stones [2]. According to data provided by the U.S. National Health Interview Survey (1990-1992) $\sim 1$ million people a year suffer from stone disease [3]. This condition affects $1-20 \%$ of the general population, with a lifetime incidence of $2-5 \%$ in Asia, $8-15 \%$ in Europe and North America, and 20\% in Saudi Arabia [4]. Geographic variability of kidney stones exists in the United States, with the highest prevalence in the southeastern states [5]. The incidence and prevalence of stone disease also varies according to age, race, and gender. The prevalence of stone disease increases with age until age 70 , when it declines, and a family history of kidney stones substantially increases risk [6]. Idiopathic stone disease occurs more frequently in white Caucasians than in Blacks, irrespective of the geographic area concerned and ethnic factors may have some effects on the male-to-female ratio among stone formers. All reports from white populations describe a male-tofemale ratio higher than 1 [7]. The increase in frequency of stones in the developed nations of the world is closely correlated with rising affluence and an increased per capita expenditure on food [8].

\subsection{Pathogenesis}

It is possible to diagnose the probable pathogenic cause of stone disease in more than $95 \%$ of patients [9]. In general, the crystallization of stone-forming salts is due to an abnormal urinary composition that is either higher in crystallization promoters (e.g. calcium, oxalate, uric acid) or lower in inhibitors (e.g. citrate, glycosaminoglycans, kidney proteins such as nephrocalcin, Tamm-Horsfall mucoprotein, uropontin), or both [7].

The mechanisms of crystallisation need to be understood to outline the basis of stone formation (Table 1). The states of saturation of ions in a solution are governed by their concentrations. For example, when concentrations of calcium and oxalate reach saturation (the saturation product), stone formation begins with association of small amounts of crystalloid to form nuclei (nucleation). These nuclei normally grow and aggregate on surfaces such as collecting ducts and renal papillary epithelium [10]. Renal epithelial cells specifically bind and

Table 1

Renal stone formation [14]

\begin{tabular}{ll}
\hline Mechanism & Mediators \\
\hline Saturation/supersaturation & Dietary habits/inborn abnormalities \\
Crystallization & Inhibitors/promoters \\
Crystal retention & Crystal size/crystal adherence/inhibitors \\
Stone formation & Continuous crystal retention \\
\hline
\end{tabular}


internalise calcium oxalate monohydrate crystals. Events that occur after crystal binding could be important in pathogenesis of stones, i.e. cellular responses might be essential for initiation of stone formation [11].

Fortunately, stone formation is inhibited in urine of mammals by substances that prevent crystallisation, and will only take place once the formation product (the metastable limit) has been exceeded. Therefore, crystallisation in undiluted human urine will begin only in a supersaturated solution of calcium and oxalate. Estimates of urine saturation with stone-forming salts such as calcium, phosphate, urate, and oxalate are important in calculation of overall propensity to crystal formation. Urinary saturation with calcium oxalate is common in the general population so the role of other factors in stone formation must be crucial [12].

Lithogenic risk factors are shown in Table 2 and include stone promoters and inhibitors. Inhibitors act by absorption on the crystal surface, interfering with the formation of the crystal lattice and retarding the attachment of new ions, thus inhibiting nucleation, and most importantly, growth and aggregation into larger crystals. Effects of inhibitors on stone forma-

Table 2

Urinary stone promoters and inhibitors [12]

\begin{tabular}{l} 
Promoters \\
Calcium \\
Sodium \\
Oxalate \\
Urate \\
Cystine \\
Low urine pH \\
Tamm-Horsfall protein \\
Low urine flow \\
Bacterial products \\
Inhibitors \\
Inorganic \\
Magnesium \\
Pyrophosphate \\
Citrate \\
Organic \\
Nephrocalcin \\
Tamm-Horsfall protein \\
Urinary prothrombin fragment 1 \\
Protease inhibitor: inter-alfa-inhibitor \\
Glycosaminoglycans \\
High urine flow \\
\hline
\end{tabular}

tion have been mainly studied in calcium oxalate stones. Most inhibitors are anionic and seem to exert their effects by binding to the calcium oxalate surface, although the specific structural mechanisms of this process are not completely known [13].

Numerous nephrolithiasis-related urinary proteins have been identified over the years. What these proteins have in common is that they are present in renal stones, are expressed and synthesized in the kidney, and modulate crystal nucleation, growth or aggregation. Besides their role as inhibitors of crystallization, these proteins are also involved in inflammation-mediated tissue repair. This is the basis for the concept that the response of renal tissue to injury might play an important role in the etiology of kidney stones [14].

The many proteins found in stones could cause, be the result of, or have no role in their formation. The most important described are: nephrocalcin, an acidic protein of renal tubular origin, and in some people who form stones this protein lacks the amino acid, $\gamma$-carboxyglutamic acid, which reduces its ability to inhibit nucleation. Additionally, nephrocalcin inhibits calcium oxalate aggregation, which some believe is a crucial step in initiation of stone formation [15]. Tamm-Horsfall protein (TPH) is the most abundant protein in human urine, and is synthesised and secreted by epithelial cells of the thick ascending limb of the loop of Henle and early distal convoluted tubule. THP remains on crystal surfaces, and thus mainly affects aggregation of preformed crystals, although controversy still exists about whether this protein is a promoter or inhibitor of crystallisation [16]. Of considerable interest is the role of proteins that are incorporated in substantial amounts in renal stones, and their effects on stone formation. One such protein, crystal matrix protein or prothrombin fragment 1 , is a peptide generated from sequential cleavage of prothrombin by factor $\mathrm{Xa}$ and thrombin. In the kidney the protein is synthesized in the proximity of renal stones. This peptide inhibits calcium oxalate crystal aggregation and growth in rats [17], and might be excreted by the kidney to protect against stone formation, but further research is required to show that this process occurs in people. The peptide chain of inter-alfa-trypsin inhibitor has been isolated from urine and is considered to be a nephrolithiasis-related protein because it 
is present in the matrix of calcium crystals generated in human urine. It has been reported to inhibit calcium oxalate crystallisation [18], although research on this protein continues. Lastly, glycosaminoglycans (GAGS), or urinary polyanions, are potent inhibitors of growth of calcium oxalate in urine, and block adhesion of uric acid crystals [19].

Compounds such as citrate and phosphate form complexes with calcium, and elements such as magnesium and sodium form complexes with oxalate, effectively reducing the free ionic concentration of each. Other factors need to be considered in the crystallisation. Uric acid can precipitate in persistently acid urine, even in the absence of hyperuricemia or hyperuricosuria. Therefore urine $\mathrm{pH}$ must be measured. Moreover, uric acid can cause precipitation of calcium oxalate stones without being incorporated into the crystals. This catalyst-like ability is known as salting out, and is enhanced in acid urine. Urinary $\mathrm{pH}$ has an essential role in many other inhibitor or promoter reactions [12].

Discussions continue as to whether obstruction or metabolic abnormalities contribute more to stone formation. Although renal stasis associated with congenital ureteropelvic junction obstruction may contribute to the formation of stones, metabolic abnormalities predisposing to stone formation tend to be present more frequently in patients with ureteropelvic junction obstruction who have stones than in those who do not.

There is evidence for genetic susceptibility to the development of calcium stone disease. Three or four loci may be involved, perhaps affecting calcium, oxalate and citrate excretion [20].

The degree to which different risk factors contribute to stones disease varies in different populations. A recent review of 1270 patients evaluated for recurrent stone disease in Texas found the following distribution [21]. Many patients had more than one risk factor.

- Hypercalciuria: 61\%, including some patients with primary hyperparathyroidism

- Hyperuricosuric calcium stones: $36 \%$

- Gouty diathesis: $10 \%$; these patients had normal urinary uric acid excretion but a low urine $\mathrm{pH}$ and developed either calcium or uric acid stones
- Hypocitraturia: $28 \%$ idiopathic and $3.3 \%$ due to distal renal tubular acidosis or chronic diarrhoea

- Hyperoxaluria: 8\%, including enteric and primary forms and markedly increased oxalate intake

- Low urine volume ( $<1$ 1/day): $15 \%$

Other types of stones were less common:

- Struvite stones: $6 \%$

- Cystine stones: $0.9 \%$

- Difficult to classify due to borderline abnormal values: $3.5 \%$

- No metabolic abnormality: $4 \%$

The risk factor due to some drug treatments cannot be forgotten. Drugs associated with stone formation include triamterene (Dyrenium) and the sulfonamides, which have low solubility. Calcium and vitamin D supplements cause hypercalciuria, and carbonic anhydrase inhibitors, which are used to treat glaucoma, increase the urinary $\mathrm{pH}$ and precipitate calcium phosphate. Indinavir (Crixivan), a protease inhibitor, can also crystallize and form stones in the urinary tract [22].

\subsection{Stone types}

There are several types of renal stones that differ in composition and pathogenesis. The most common type of kidney stone is composed of calcium oxalate and is caused by metabolic disorders that are often treatable.

\subsubsection{Calcium stones}

Most stones contain calcium combined with oxalate, phosphate, or occasionally uric acid. All calcium stones are radio-opaque, and calcium oxalate and calcium phosphate stones are black, grey, or white and small $(<1 \mathrm{~cm}$ in diameter), dense, and sharply circumscribed on radiographs. Different conditions contribute to calcium stones.

Hypercalciuria (defined as $>0.1 \mathrm{mmol} / \mathrm{kg}$ bodyweight of patient per day, calculated for ideal bodyweight) can be idiopathic or result from any disorder that induces even mild hypercalcemia. Such disorders include: (i) primary hyperparathyroidism; (ii) other disorders that induce hypercalcemia such 
as malignancies, granulomatous diseases, sarcoidosis, thyrotoxicosis, and immobilisation; (iii) idiopathic hypercalciuria, a familial disorder affecting both sexes equally, in which urinary calcium concentration is raised despite normal concentrations of blood calcium; (iv) mutations in the CLCN5 chloride channel in Japanese patients which resulted in low-molecular-weight proteinuria, hypercalciuria, and calcium stone formation [23]; and (v) other causes of hypercalciuria are inherited syndromes of familial benign and autosomal dominant hypercalciuric hypocalcemia.

It has been proposed that there are three forms of idiopathic hypercalciuria: (i) absorptive hypercalciuria in which there is an increase in intestinal calcium absorption; this is the most common form; (ii) fasting hypercalciuria in which the excess calcium may be coming from bone; and (iii) renal hypercalciuria in which there is a defect in renal tubular calcium reabsorption. The clinical and pathogenetic significance of this classification is uncertain.

Another condition associated with renal stone formation is hyperoxaluria. Urinary oxalate is an end-product of metabolism primarily derived from the metabolism of glycine (40\%) and ascorbic acid (40\%), with dietary oxalate accounting for $\sim 10 \%$. The role played by diet is related to the limited intestinal absorption of oxalate ( $10 \%$ of intake) due in part to the formation of insoluble calcium oxalate salts in the intestinal lumen.

Foods rich in oxalate: rhubarb, standard teas, nuts, beans, spinach, coffee, and chocolates can increase concentrations in urine to $670 \mathrm{mmol} /$ day (normal value $440 \mathrm{mmol} / \mathrm{day})$. However, concentrations of more than $890 \mathrm{mmol} /$ day indicate enteric oxaluria (associated with malabsorptive small-bowel diseases), mild metabolic hyperoxaluria, or primary hyperoxaluria. Mild metabolic hyperoxaluria does not seem to represent a substantial fraction of hyperoxalurias. Although the exact pathogenic mechanisms have not been identified, cytosolic enzyme perturbations are thought to result in mild hyperoxaluria and recurrent calcium oxalate stones. Primary hyperoxaluria type 1 (PH I) disease is caused by lack of the liver enzyme alanine glyoxylate aminotransferase, and type 2 disease (PH II) by lack of Dglycerate dehydrogenase [24]. The defective genes that cause these diseases and their abnormal liver enzyme products cause excessive oxalate metabolism, which results in systemic calcium oxalate deposition from a young age.

Finally, hypocitraturia is also associated with renal lithogenesis. Citrate acts in the tubular lumen by combining with calcium to form a non-dissociable but soluble complex. As a result, there is less free calcium available to combine with oxalate. In addition, citrate also appears to inhibit the important process of crystal agglomeration, in which individual calcium oxalate crystals combine to form a stone. Hypocitraturia could result from causes of intracellular acidosis such as renal failure, potassium deficiency, distal renal tubular acidosis, chronic diarrhoeal states, and drugs such as acetazolamide. Many patients with stones have unexplained low urinary citrate and dysfunction of the renal sodium citrate cotransporter has been proposed as a possible mechanism [25].

\subsubsection{Uric acid stones}

Uric acid stones are smooth, round, yellow-orange and nearly radiographically transparent unless mixed with calcium crystals or struvite. Diets high in purines, especially those containing meats and fish, result in hyperuricosuria, and, in combination with low urine volume and low urinary $\mathrm{pH}$, can exacerbate uric acid stone formation. Uric acid salts out calcium oxalate, and can precipitate out in acid urine even in the absence of raised serum or urinary uric acid concentrations. Furthermore, hyperuricemic disorders including gout ( $20 \%$ of patients with gout are hyperuricosuric), myeloproliferative disorders, tumor lysis syndrome, and inborn errors of metabolism (such as Lesch-Nyhan syndrome and glucose-6phosphatase deficiency) result in an increased filtered load of uric acid and thus, hyperuricosuria [26]. As with all stones, certain drugs may enhance stone formation, and in the case of uric acid stones, hyperuricosuric agents include low dose salicylates, probenecid, and thiazides.

\subsubsection{Struvite or triple phosphate stones}

Struvite is a crystalline substance composed of magnesium ammonium phosphate. Radiographs show struvite stones as large, gnarled, and laminated. They are associated with substantial morbidity including bleeding, obstruction, and urinary tract in- 
fection. Signs of struvite stones include urinary $\mathrm{pH}$ greater than 7, staghorn calculi, and urease that grows bacteria on culture (proteus, klebsiella, pseudomonas) [27]. Stones develop if urine is alkaline, has a raised concentration of ammonium, contains trivalent phosphate, and contains urease produced by bacteria. A recent work [28] has suggested that not only struvite stones, but also calcium based stones may have an infectious origin.

\subsubsection{Cystine stones}

Formation of cystine stones is the only clinical expression of cystinuria, an autosomal recessive disorder. People who are homozygous for cystinuria excrete more than $600 \mathrm{mg}$ per day of insoluble cystine, so cystine stones should be suspected in patients with a history of childhood stones or a strong family history. Cystinuria is the cause of $1-2 \%$ of stones observed in adults and $\sim 10 \%$ of those occurring in children. The stones are greenishyellow, flecked with shiny crystallites, and are moderately radio-opaque with a rounded appearance. More than half the stones in cystinuria are of mixed composition, and many patients have associated physiological problems such as hypercalciuria (19\% of patients), hyperuricosuria (22\%), and hypocitraturia $(44 \%)$ [29].

\subsubsection{Protease-related stones}

This is the newest type of stone described. The increasing incidence of HIV-positive patients has led to widespread use of the protease inhibitor indinavir sulphate [30]. Although the drug is generally well tolerated, it can be associated with urolithiasis in $4-12 \%$ of patients [31]. Thus, calcium oxalate stones may coexist or form a nidus for indinavir stones or vice versa.

\section{Stone analysis}

All available stones should be analyzed to determine their crystalline composition. Stone analysis is requested less frequently than it was 20 years ago. This has coincided with the general move away from manual laboratory methods of analysis and the advent of endoscopic stone removal and extracorporeal shock-wave lithotripsy.

Although stone analysis is beyond the scope of this work, we will briefly comment on the subject with some references of last few years. Stones are analyzed by optical crystallography supplemented when necessary by X-ray diffraction and infrared spectroscopy.

Many types of stones have a characteristic X-ray appearance. Examples include cystine stones (rounded and mildly opaque), struvite (branching and take the form of calices), uric acid (radiolucent) and oxalate (may have the typical Jack Stone or hair-onend appearance) [32]. Traditionally, this is the technique of choice for the determination of particle size and composition of biological crystals. However, ground samples are required, thereby prohibiting the analysis of the morphological distribution of components.

Infrared spectroscopy is useful for identification of non-crystalline material, including amorphous substances and drug metabolites that are not detected with other techniques [33]. The application of infrared and Raman spectroscopy techniques to the analysis of urinary calculi was reviewed by Carmona et al. [34] and their relative efficiency and adaptability to routine analysis have been discussed. Paluszkiewicz et al. [35] linked structural composition of renal stones, determined by Fourier transform infrared spectroscopy and Fourier transform Raman spectroscopy, with elemental composition determined using proton-induced X-ray emission and atomic emission spectroscopy.

Other authors focus their work on Fourier transform infrared spectroscopy and provide their experience and data on more than 12000 calculi analyzed [36]. The potentialities of the alternative Raman spectroscopy have also been explored [37].

Qualitative and quantitative chemical analysis [38] is unsatisfactory because of false positive and false negative reactions.

Recent advances enable radiologists examine tissues and structures using three-dimensional figures constructed from the multiple planar images acquired during spiral computerized tomography (CT) examination. Three-dimensional CT techniques permit the linear dimensions of renal calculi to be determined along all three coordinate axes [39]. The precise 
Table 3

Summary of recommendations from the NIH Consensus Conference on the Evaluation of Stone Formers ${ }^{\mathrm{a}}$

Evaluation of patient with first stone episode

History: medications, occupation, family history of stones or other kidney disease,

inflammatory bowel disease (e.g. Crohn's disease)

Diet: intake of protein, purines, sodium, fluids, oxalate and calcium

Laboratory tests: electrolyte, blood urea nitrogen, creatinine, calcium, phosphate and

uric acid levels, urinalysis, urine culture if indicated, stone analysis if available (if not,

consider qualitative cystine screening)

Radiology: plain radiographs, ultrasonography and/or intravenous pyelography (or helical

computed tomography) to find more stones, radiolucent stones or anatomic abnormalities

Consider: renal tubular acidosis, hyperparathyroidism and sarcoidosis

Evaluation of patient with recurrent stone formation (and all children)

24-h urine collection: volume, $\mathrm{pH}$, levels of calcium, phosphorus, sodium, uric acid, oxalate,

citrate, creatinine, calcium oxalate (supersaturation), calcium phosphate and uric acid

Repeat as necessary: 24-h urine collection and analysis to monitor response to dietary

changes and effectiveness of treatment

${ }^{\mathrm{a}} \mathrm{NIH}$, National Institutes of Health.

chemical composition of uric acid, struvite and calcium oxalate stones has also been identified by $\mathrm{CT}$ in an in vitro setting [40].

The applicability of solid state NMR spectroscopy has been investigated to obtain information about the structure and composition of renal calculi. ${ }^{13} \mathrm{C}$ and

${ }^{31} \mathrm{P}$ MAS NMR analysis have accounted for $60-85 \%$ (by weight) of the constituents (crystalline and amorphous) in renal calculi [41].

\section{Urine analysis}

All patients with kidney stones should be investigated [42] and assessment needs to include a thorough medical history, drugs taken, family history, lifestyle and diet, fluid intake, and a clinical examination. Fasting blood tests should include those for full blood count and urea, electrolytes, calcium, phosphate, bicarbonate, uric acid, alkaline phosphatase, cholesterol and parathyroid hormone. A fasting urine sample is used for routine urinalysis, for culture when indicated, and for calcium, creatinine and $\mathrm{pH}$ testing. In the assessment of patients with urinary stone disease, 24-h urine analysis is easy to perform, gives important information on the risk of recurrent stone formation and includes measurement of urinary volume, calcium, sodium, urate, creatinine, phosphate, citrate and oxalate. Table 3 summarizes the Recommendations from the National Institutes of Health (NIH) Consensus Conference on the Evaluation of Stone Formers [43].

The upper limits of normal values for the main parameters (in $\mathrm{mg}$ /day) are shown in Table 4 [44]. Recently, Curhan et al. reported normal 24-h urine values in men and women participants in the Nurses Health Study [45].

Repetitive collections allow evaluation of patient compliance and risk. Diagnostic information from limited (i.e. one/two random 24-h urine collections) and comprehensive (i.e. two random 24-h urine collections, one 24-h collection after 1 week of

Table 4

Normal values of biochemical risk factors for renal stones in urine

\begin{tabular}{lcc}
\hline & Men & Women \\
\hline Calcium & $<300 \mathrm{mg} /$ day $(7.5 \mathrm{mmol} /$ day $)$ & $<250 \mathrm{mg} /$ day $(6.25 \mathrm{mmol} /$ day $)$ \\
Uric acid & $<800 \mathrm{mg} /$ day $(4.8 \mathrm{mmol} /$ day $)$ & $<750 \mathrm{mg} /$ day $(4.5 \mathrm{mmol} /$ day $)$ \\
Citrate & $450-600 \mathrm{mg} /$ day $(2.3-3.1 \mathrm{mmol} /$ day $)$ & $650-800 \mathrm{mg} /$ day $(3.4-4.2 \mathrm{mmol} / \mathrm{day})$ \\
Oxalate & $<45 \mathrm{mg} /$ day $(0.5 \mathrm{mmol} /$ day $)$ & $<45 \mathrm{mg} /$ day $(0.5 \mathrm{mmol} /$ day $)$ \\
\hline
\end{tabular}


dietary restrictions, calcium load and blood work over an 11-day period) metabolic evaluations of recurrent calcium stone formers was compared. The comprehensive metabolic evaluation yielded a specific metabolic diagnosis in $90 \%$ of the patients; this contrasts with the diagnosis rates for one $(68 \%)$ and two $(75 \%)$ urinalyses [30]. Table 5 summarises the main techniques for nephrolithiasis markers analysis. It will be commented on below.

\subsection{Sample collection and storage}

Sample collection and storage conditions are critical to securing meaningful results for diagnosis and treatment. The 24-h urine collections should be obtained in the outpatient setting when the patient is on his or her regular diet. It is very important to provide clear instructions and the necessary containers preferably with a preservative to prevent bacterial growth or with $\mathrm{HCl}$ for oxalate measurements $(30 \mathrm{ml}$ for adults or $10 \mathrm{ml}$ for pediatric patients of $6 \mathrm{~N} \mathrm{HCl}$ ). The specimens must be refrigerated after collection. Measurement of creatinine excretion permits assessment of the completeness of the 24-h collection. The normal rate of urinary creatinine excretion in patients under the age of 50 is $20-25 \mathrm{mg} / \mathrm{kg}$ lean body weight in men and $15-20 \mathrm{mg} / \mathrm{kg}$ lean body weight in women, and values substantially below this level suggest incomplete collection.

An open question with regard to supersaturation measurements is how well a sparse sample can represent the average supersaturation present over the months to years during which stones form and grow. In a large group of patients with no systemic cause of stones, Parks et al. [46] showed that urine supersaturation with respect to calcium oxalate, brushite and uric acid in three 24-h outpatient urine collections, closely reflects the average driving forces in the nephron that control formation of the solid phases of kidney stones. Similar results were obtained with two 24-h urine samples collected from 183 patients at six treatment sites. Urine supersaturation values correlated well with stone composition. In a validation study values of relevant urine materials were unchanged after 48 -h aging. Samples were collected with thymol as the preservative [47].

On the other hand, the diagnosis of oxalosis rests on the finding of increased urinary oxalate excretion in 24-h urine. In primary hereditary hyperoxaluria, stone formation usually begins in childhood, $65 \%$ of the cases before age 12 [48], and it is sometimes troublesome and inaccurate to collect 24-h urine volumes in infants and toddlers without bladder catheterization. Itami et al. have found highly significant positive correlations $(r=0.96)$ between urinary oxalate/creatinine ratio in first-voided urine in the morning and 24-h oxalate excretion when corrected for the body surface area, both investigated in normal children and in patients.

Finally, the possibility of filter paper collection has also been studied. The urines were preserved with $6 \mathrm{M} \mathrm{HCl}$ to prevent non-enzymatic conversion of ascorbate to oxalate, as will be explained next. Filter paper strips were dipped into the urine and left to dry at room temperature. Oxalate, glycolate, citrate and sulfate were determined after being stored for up to 1 week without diagnostically significant changes in concentrations [49]. The advantage of this method is that samples can be mailed to specialised laboratories in envelopes, reducing shipping costs. Oxalate measurement can be influenced by in-vitro generation of oxalate from ascorbate, $\mathrm{pH}$, and certain drugs, but this point will be treated below in the Oxalate analysis section.

\subsection{Analysis of inhibitors}

\subsubsection{Macromolecules}

Kitamura et al. [50] characterized organic macromolecules in urine from patients with renal stones and control subjects. From the urine of patients with calcium nephrolithiasis, and of control subjects, organic substances were isolated according size and tested for effects on calcium oxalate precipitation. Nine subgroup materials of varying sizes were prepared by ultrafiltration and Sephadex G-200 column chromatography from ten stone formers and ten control subjects. Uromucoic was found in large materials of both groups, whereas GAGS were detected in large- and medium-sized materials of both groups. The small materials were devoid of uromucoid and GAGS, but contained protein and uronic acid, a finding suggesting that they may be glycoproteins. The daily excretion of the uromucoidrich material was greater, but that of the small 
Table 5

Summary of main techniques for nephrolithiasis markers analysis

\begin{tabular}{|c|c|c|c|c|c|c|}
\hline & Technique & Sample preparation & Analysis & Artefacts & Normal ranges & Refs. \\
\hline $\begin{array}{l}\text { Urine } \gamma \text { - } \\
\text { carboxyglutamic } \\
\text { acid (GLA) }\end{array}$ & HPLC & $\begin{array}{l}\text { Alkaline hydrolysates of protein } \\
\text { samples } \\
\text { Derivatization with } o \text {-phthalaldehyde }\end{array}$ & $\begin{array}{l}\text { Anion exchanger } \\
\text { Isocratic elution } \\
\text { Fluorescent detection }\end{array}$ & & & {$[123,124]$} \\
\hline $\begin{array}{l}\text { Urine } \gamma \text { - } \\
\text { carboxyglutamic } \\
\text { acid }\end{array}$ & HPLC & $\begin{array}{l}\text { Free GLA was removed from urine by } \\
\text { exhaustive dialysis } \\
\text { Alkaline hydrolysate } \\
\text { Derivatization with } o \text {-phthalaldehyde } \\
\text { and mercaptoethanol }\end{array}$ & $\begin{array}{l}\text { Column Spherisorb } \\
\text { ODS } 150 \times 4.6 \mathrm{~mm}, 5 \\
\mu \mathrm{m} \\
\text { Fluorescent detection }\end{array}$ & & $\begin{array}{l}\text { Healthy individuals } \\
\text { Protein-bound GLA: } 0.81 \pm 0.27 \\
\mu \mathrm{mol} / 1 \\
\text { Stone formers } \\
\text { Protein-bound GLA: } 0.83 \pm 0.38 \\
\mu \mathrm{mol} / 1\end{array}$ & {$[53]$} \\
\hline $\begin{array}{l}\text { Urine } \\
\text { citrate (CIT) }\end{array}$ & Enzymatic & $\begin{array}{l}\text { Acidified sample was incubated with } \\
\text { citrate lyase to form oxaloacetate } \\
\text { Neutralised with Bis-Tris buffer }\end{array}$ & $\begin{array}{l}\text { Derivatization with } \\
\text { phenylhydrazine } \\
\lambda \text { 330-nm absorption }\end{array}$ & & Linear up to $10 \mathrm{mmol} / \mathrm{l}$ & {$[58]$} \\
\hline $\begin{array}{l}\text { Urine and blood } \\
\text { uric acid (UA) }\end{array}$ & $\begin{array}{l}\text { Differential pulse } \\
\text { voltammetry (DPV) } \\
\text { and } \\
\text { chronoamperometry } \\
\text { (CHRA) }\end{array}$ & $\begin{array}{l}\text { Urine was diluted ( } 10000 \text {-fold) with } \\
0.1 \mathrm{HClO}_{4} \\
\text { Serum was diluted by a factor of } 200\end{array}$ & $\begin{array}{l}\text { Three-electrode glass } \\
\text { cell } \\
\text { Measurements without } \\
\text { removing dissolved } \\
\text { oxygen } \\
\text { Diamond thin-film } \\
\text { electrode mounted with } \\
\text { epoxy }\end{array}$ & $\begin{array}{l}\text { Presence of high } \\
\text { concentrations of } \\
\text { ascorbic acid does } \\
\text { not interfere }\end{array}$ & $\begin{array}{l}\text { Urine } \\
\text { Uric acid } \\
1.5-10 \mathrm{~m} M \\
\text { Linear up to } 75 \mu M(\mathrm{DPV}) \\
\text { Linear over the range } 5 \times 10^{-8} \\
-1 \times 10^{-6} M \text { (CHRA) }\end{array}$ & {$[75]$} \\
\hline $\begin{array}{l}\text { Urine and plasma } \\
\text { glycolate (GLY) }\end{array}$ & a Enzymatic & $\begin{array}{l}\text { Sample incubated with glycolate } \\
\text { oxidase/peroxidase } \\
\text { Interferences from plasma were } \\
\text { removed with deproteinisation } \\
\text { and from urine with charcoal }\end{array}$ & $\begin{array}{l}\mathrm{H}_{2} \mathrm{O}_{2} \text { coupled to } \\
\text { sulphonated 2,4,- } \\
\text { dichlorophenol and 4- } \\
\text { aminophenazone to } \\
\text { form quinoneimine dye } \\
\lambda \text { 515-nm absorption }\end{array}$ & $\begin{array}{l}\text { Total absorbance } \\
\text { obtained is due to } \\
\text { glycolate and } \\
\text { lactate absorption }\end{array}$ & $\begin{array}{l}\text { Normal subject } \\
\text { GLY: } 0.239 \mathrm{mmol} / 24 \mathrm{~h} \text { (urine) } \\
0.125 \mathrm{mmol} / 1 \text { (plasma) } \\
\text { Patient with primary } \\
\text { hyperoxaluria } \\
\text { GLY: } 1.14 \mathrm{mmol} / 24 \mathrm{~h} \text { (urine) }\end{array}$ & {$[80]$} \\
\hline $\begin{array}{l}\text { Urine } \\
\text { glycolate }\end{array}$ & HPLC & $\begin{array}{l}\text { GLY: sample plus chlorhexidine } \\
\text { gluconate as preservative was } \\
\text { incubated with glycolate oxidase to } \\
\text { convert GLY in GLX } \\
\text { Derivatization with phenylhydrazine }\end{array}$ & $\begin{array}{l}\text { Column: Lichrospher } \\
\text { RP-18 } 10 \mu \mathrm{m} 250 \times 4 \\
\text { mm } \\
\text { Isocratic elution } \\
\text { Mobile phase: } 0.15 \mathrm{M} \\
\text { acetic acid:MeOH } \\
\text { (88:12) } \\
\lambda \text { 324-nm absorption }\end{array}$ & $\begin{array}{l}\text { Different compounds } \\
\text { do not offer } \\
\text { interferences }(n>16)\end{array}$ & $\begin{array}{l}\text { Urine } \\
\text { Healthy controls }(n=25) \\
\text { GLY: } 450 \pm 139.9 \mu \mathrm{mol} / 1 \\
\text { Hyperoxaluria Type I }(n=6) \\
\text { GLY: } 6167 \pm 4616 \mu \mathrm{mol} / 1\end{array}$ & {$[82]$} \\
\hline $\begin{array}{l}\text { Urine } \\
\text { glycolate }\end{array}$ & HPLC & $\begin{array}{l}\text { GLY: sample plus chlorhexidine } \\
\text { gluconate as preservative was } \\
\text { incubated with glycolate oxidase to } \\
\text { convert GLY in GLX } \\
\text { Derivatization with phenylhydrazine }\end{array}$ & $\begin{array}{l}\text { Column: Lichrospher } \\
\text { RP-18 } 10 \mu \mathrm{m} 250 \times 4 \\
\text { mm } \\
\text { Gradient elution } \\
\text { Mobile phase: } 0.15 \mathrm{M} \\
\text { Phosphate buffer:EtOH } \\
\text { (97:3-46:54) } \\
\lambda \text { 324-nm absorption }\end{array}$ & & $\begin{array}{l}\text { Urine } \\
\text { Healthy controls }(n=14) \\
\text { GLY: } 468.8 \pm 124.5 \mu \mathrm{mol} / 24 \mathrm{~h} \\
41.6 \pm 11.9 \mu \mathrm{mol} / \mathrm{mmol} \\
\text { creatinine } \\
\text { Hyperoxaluria Type I }(n=5) \\
\text { GLY: } 3722 \pm 4951 \mu \mathrm{mol} / 24 \mathrm{~h} \\
\text { 535.8 } \pm 218.8 \mu \mathrm{mol} / \mathrm{mmol} \\
\text { creatinine }\end{array}$ & {$[83]$} \\
\hline \multicolumn{2}{|c|}{$\begin{array}{l}\text { Urine and plasma HPLC } \\
\text { glycolate (GLY) } \\
\text { oxalate }(\mathrm{OX})\end{array}$} & $\begin{array}{l}\text { GLY: sample incubated with glycolate } \\
\text { oxidase } \\
\text { Derivatization with phenylhydrazine } \\
\text { OX: plasma centrifuged plus } \mathrm{HCl} \\
\text { precipitated proteins with acetonitrile }\end{array}$ & $\begin{array}{l}\text { GLY: as previously } \\
\text { described [82] } \\
\text { OX: ion } \\
\text { chromatography with } \\
\text { conductimetric detector }\end{array}$ & & $\begin{array}{l}\text { Urine } \\
\text { Healthy controls }(n=19) \\
\text { GLY: } 422 \pm 137 \mu \mathrm{mol} / 24 \mathrm{~h} \\
\text { Plasma } \\
\text { Healthy controls }(n=19) \\
\text { GLY: } 7.9 \pm 2.4 \mu \mathrm{mol} / 1\end{array}$ & [125] \\
\hline
\end{tabular}


Table 5. Continued

\begin{tabular}{|c|c|c|c|c|c|c|}
\hline & Technique & Sample preparation & Analysis & Artefacts & Normal ranges & Refs. \\
\hline $\begin{array}{l}\text { Blood } / \text { dialysate } \\
\text { glycolate } \\
\text { oxalate }\end{array}$ & HPLC & $\begin{array}{l}\text { GLY: sample incubated with glycolate } \\
\text { oxidase } \\
\text { Derivatization with phenylhydrazine }\end{array}$ & $\begin{array}{l}\text { Column: Spherisorb } \\
\text { ODS, } 10 \mu \mathrm{m} 250 \times 4 \mathrm{~mm} \\
\text { Mobile phase: } \\
\text { phosphate } \mathrm{pH} 7 / \mathrm{MeOH} \\
(90: 10) \\
\lambda \text { 324-nm absorption } \\
\text { OX: ion } \\
\text { chromatography/ } \\
\text { conductimetry detector }\end{array}$ & $\begin{array}{l}\text { Different } \\
\text { compounds do not } \\
\text { offer interferences } \\
(n>16)\end{array}$ & $\begin{array}{l}\text { Plasma } \\
\text { Healthy controls }(n=12) \\
\text { GLY: } 7.8 \pm 1.7 \mu \mathrm{mol} / 1 \\
\text { Linear up to } 0.2 \mathrm{mmol} / 1 \\
\text { OX: } 6.1 \pm 1.6 \mu \mathrm{mol} / 1 \\
\text { Oxalosis Type I }(n=4) \\
\text { GLY: } 1536 \pm 1062 \mu \mathrm{mol} / 1 \\
\text { OX: } 162.0 \pm 24.0 \mu \mathrm{mol} / 1\end{array}$ & [125] \\
\hline $\begin{array}{l}\text { Urine } \\
\text { glycolate (GLY) } \\
\text { glycerate (GLYC) } \\
\text { oxalate (OX) }\end{array}$ & Gas chromatography & $\begin{array}{l}\text { Urine adjusted to } \mathrm{pH} 2 \text {, saturated with } \\
\mathrm{NaCl} \\
\text { Extraction: three times diethyl ether and five } \\
\text { times } \mathrm{THF} \\
\text { Residue derivatized pyridine:BSTFA } \\
(1: 1)\end{array}$ & $\begin{array}{l}\text { DB-1 column }(0.53 \\
\text { mm I.D.) } \\
\text { Gradient temperature } \\
\text { FID detector/MS }\end{array}$ & $\begin{array}{l}\text { Does not } \\
\text { distinguish } \\
\text { between D/L } \\
\text { GYC forms }\end{array}$ & $\begin{array}{l}\text { GLY: } 14-72 \mu \mathrm{g} / \mathrm{mg} \text { creatinine } \\
(n=65) \\
\text { GLC: } 0-5 \text { years: } 12-177 \mu \mathrm{g} / \mathrm{mg} \\
(n=19) \\
>5 \text { years: } 19-115 \mu \mathrm{g} / \mathrm{mg}\end{array}$ & [84] \\
\hline $\begin{array}{l}\text { Body fluids } \\
\text { L-Glyceric } \\
\text { (GLYC) }\end{array}$ & HPLC & $\begin{array}{l}\text { LDH/NAD oxidation of L-glycerate } \\
\text { into } \beta \text {-hydroxypyruvate } \\
\text { Derivatization with phenylhydrazine }\end{array}$ & $\begin{array}{l}\text { Column: Lichrospher } \\
\text { RP-18 } 5 \mu \mathrm{m} 250 \times 4 \\
\mathrm{~mm} \\
\text { Isocratic elution } \\
\text { Mobile phase: A/B } \\
\text { (83:17) phosphate } \\
\text { buffer/acetonitrile } \\
\lambda \text { 324-nm absorption }\end{array}$ & $\begin{array}{l}\text { Samples analysed } \\
\text { within } 2 \text { weeks } \\
\text { Samples required } \\
\text { long periods of } \\
\text { incubation }(>5 \mathrm{~h})\end{array}$ & $\begin{array}{l}\text { Urine and plasma } \\
\text { Normal individuals } \\
\text { L-GLYC: }<5 \mu \mathrm{mol} / 1 \\
\text { Linear up to } 500 \mu \mathrm{mol} / 1 \\
\text { Hyperoxaluria type II }(n=1) \\
\text { L-GLYC: } 887 \mu \mathrm{mol} / 1 \text { (plasma) }\end{array}$ & [126] \\
\hline $\begin{array}{l}\text { Urine } \\
\text { oxalate }(\mathrm{OX})\end{array}$ & Enzymatic & $\begin{array}{l}\mathrm{HCl} \text { acidified urine, passed through } \\
\text { ion-exchange column and eluted with } \\
0.1 \mathrm{~mol} / 1 \mathrm{HCl} \\
\text { Sample incubated with oxalate oxidase } \\
\text { Interferences were removed with } \\
\text { ascorbate oxidase }\end{array}$ & $\begin{array}{l}\text { Centrifugal analyzer } \\
\text { Reaction with 3- } \\
\text { methyl-2- } \\
\text { benzothiazolinone } \\
\text { hydrazone and } N, N \text { - } \\
\text { dimethylaniline/ } \mathrm{HCl} \\
\lambda \text { 595-nm absorption }\end{array}$ & & $\begin{array}{l}\text { Urine } \\
\text { Healthy controls }(n=28) \\
\text { OX: } 0.35 \pm 0.078 \mathrm{mmol} / 1 \\
\text { Linear up to } 1 \mathrm{mmol} / 1\end{array}$ & [127] \\
\hline $\begin{array}{l}\text { Urine } \\
\text { oxalate }\end{array}$ & Enzymatic & $\begin{array}{l}\mathrm{HCl} \text { acidified urine was neutralised and } \\
\mathrm{OX} \text { precipitated with ethanol, dried } \\
\text { and dissolved } \mathrm{in}_{2} \mathrm{SO}_{4} \text { and citrate } \\
\text { buffer } \\
\text { Sample incubated with oxalate } \\
\text { decarboxylase and formate } \\
\text { dehydrogenase }\end{array}$ & $\begin{array}{l}\text { Centrifugal analyzer } \\
\lambda \text { 340-nm absorption }\end{array}$ & & & [128] \\
\hline $\begin{array}{l}\text { Urine } \\
\text { oxalate }\end{array}$ & Enzymatic & $\begin{array}{l}\text { Precipitation of oxalate with } \mathrm{CaSO}_{4} \\
\text { and a } 10 \text {-fold dilution in sulfuric acid }\end{array}$ & $\begin{array}{l}\text { Centrifugal analyzer } \\
\text { Reaction with 3- } \\
\text { methyl-2- } \\
\text { benzothiazolinone } \\
\text { hydrazone and } N, N \text { - } \\
\text { dimethylaniline/ } \mathrm{HCl} \\
\lambda \text { 595-nm absorption }\end{array}$ & & & [129] \\
\hline $\begin{array}{l}\text { Urine } \\
\text { oxalate }\end{array}$ & Enzymatic & $\begin{array}{l}\mathrm{HCl} \text { acidified urine was diluted } \\
\text { EDTA to increase the } \mathrm{pH} \\
\text { Sample incubated with oxalate } \\
\text { oxidase/peroxidase } \\
\text { Interferences were removed with } \\
\text { activated charcoal }\end{array}$ & $\begin{array}{l}\text { Reaction with 3- } \\
\text { methyl-2- } \\
\text { benzothiazolinone } \\
\text { hydrazone and 3- } \\
\text { (dimethylamino) } \\
\text { benzoic acid } \\
\lambda \text { 590-nm absorption }\end{array}$ & $\begin{array}{l}\text { Ascorbic acid and } \\
\text { divalent cations do } \\
\text { not interfere }\end{array}$ & Linear up to $1 \mathrm{mmol} / 1$ & [130] \\
\hline
\end{tabular}


Table 5. Continued

\begin{tabular}{|c|c|c|c|c|c|c|}
\hline & Technique & Sample preparation & Analysis & Artefacts & Normal ranges & Refs. \\
\hline $\begin{array}{l}\text { Urine and plasma } \\
\text { oxalate }\end{array}$ & $\begin{array}{l}\text { Modified enzyme- } \\
\text { based colorimetric } \\
\text { assay }\end{array}$ & $\begin{array}{l}\mathrm{HCl} \text { acidified urine was diluted with } \\
\text { EDTA to increase the } \mathrm{pH} \\
\text { Sample incubated with oxalate oxidase } \\
\text { immobilised in a nylon coil/peroxidase } \\
\text { Interferences are removed with } \\
\text { activated charcoal }\end{array}$ & $\begin{array}{l}\text { Reaction with 3- } \\
\text { methyl-2- } \\
\text { benzothiazolinone } \\
\text { hydrazone and 3- } \\
\text { (dimethylamino) } \\
\text { benzoic acid } \\
\lambda \text { 580-nm absorption }\end{array}$ & $\begin{array}{l}\text { Autoconversion of } \\
\text { ascorbate to } \\
\text { oxlate after long } \\
\text { storage times }\end{array}$ & $\begin{array}{l}\text { Urine healthy controls } \\
\text { OX: } 0.11 \pm 0.46 \mathrm{mmol} / 24 \mathrm{~h} \\
\text { Plasma control subjects } \\
\text { OX: } 2.5 \pm 0.7 \mu \mathrm{mol} / 1\end{array}$ & [91] \\
\hline $\begin{array}{l}\text { Urine } \\
\text { oxalate }\end{array}$ & Gas chromatography & $\begin{array}{l}\text { Sample dried with } \mathrm{N}_{2} \text { or lyophilised } \\
\text { Residue derivatized with } 10 \% \mathrm{BCl}_{3}: 2 \\
\text {-chloroethanol } \\
\text { Formation of bis-2-chloroethyl ester of } \\
\text { oxalic acid and extraction into ethyl } \\
\text { acetate/isopropyl ether }\end{array}$ & $\begin{array}{l}\text { Glass U column } \\
(1.8 \mathrm{~m} \times 4 \mathrm{~mm} \text { I.D. }) \\
\text { Constant temperature } \\
\text { FID detector/MS }\end{array}$ & $\begin{array}{l}\text { Many compounds } \\
\text { studied (22) do not } \\
\text { offer interferences } \\
\text { only glyceric acid }\end{array}$ & $\begin{array}{l}\text { Patient with idiopathic renal } \\
\text { stone: } 10.6-42.0 \mathrm{mg} / 24 \mathrm{~h}\end{array}$ & {$[131]$} \\
\hline $\begin{array}{l}\text { Urine and plasma } \\
\text { oxalate }\end{array}$ & Gas chromatography & $\begin{array}{l}\text { Urine and plasma: acidified, saturated } \\
\text { with } \mathrm{NaCl} \text {, extracted three times with ethyl } \\
\text { acetate and evaporated } \\
\text { Derivatization: mixture BSTFA/ } \\
\text { TMBS (30:1) }\end{array}$ & $\begin{array}{l}\text { Capillary column } 25 \mathrm{~m} \\
1 \text { SE-30 ID } 0.2 \mathrm{~mm} \\
\text { Constant temperature } \\
\text { FID detector }\end{array}$ & $\begin{array}{l}\text { Standing for longer } \\
\text { periods of time } \\
(>3 \mathrm{~h}) \text { results in a } \\
\text { gradual increase in } \\
\text { oxalate content of } \\
\text { the plasma }\end{array}$ & $\begin{array}{l}\text { Plasma healthy controls }(n=22) \\
\text { OX: } 2.8 \pm 1.1 \mu \mathrm{mol} / 1\end{array}$ & [99] \\
\hline $\begin{array}{l}\text { Urine } \\
\text { oxalate }\end{array}$ & $\begin{array}{l}\text { Gas chromatography/ } \\
\text { isotope dilution/mass } \\
\text { spectrometry }\end{array}$ & $\begin{array}{l}\text { Precipitation of } \mathrm{OX} \text { from acidified } \\
\text { urine with } \mathrm{CaSO}_{4} \text { and ethanol. } \mathrm{OX} \\
\text { converted into isopropyl-ester with } \\
\text { propane-2-ol-HCl. Extract dissolved } \\
\text { with chloroform }\end{array}$ & $\begin{array}{l}\text { Column } 25 \mathrm{~m}, 0.20 \mathrm{~mm} \\
\text { Isothermally } \\
\text { chemical ionisation } \\
\text { with ammonia } \\
\text { Quadrupole mass } \\
\text { spectrometer }\end{array}$ & & & {$[100]$} \\
\hline $\begin{array}{l}\text { Urine } \\
\text { oxalate }\end{array}$ & HPLC/ID-MS & $\begin{array}{l}\text { Comparison of three different sample } \\
\text { preparations: } \\
\text { 1. Precipitation of } \mathrm{OX} \text { with } \mathrm{CaSO}_{4} \text { and } \\
\text { ethanol } \\
\text { 2. Extraction of } \mathrm{OX} \text { by aluminium } \\
\text { hydroxide columns } \\
\text { 3. Destruction: sample incubated with } \\
\text { oxalate decarboxylase }\end{array}$ & $\begin{array}{l}\text { HPLC: } \\
\text { addition of } 1,2,- \\
\text { phenylenediamine/HCl } \\
\text { Column: Spherisorb } \mathrm{C}_{18} \\
(100 \times 4.6 \mathrm{~mm}) \\
\text { Mobile phase: } \mathrm{MeOH} \\
\text { /tetrahydrofurane } \\
\text { ammonium acetate/ } \\
\lambda 314 \mathrm{~nm}\end{array}$ & & & {$[132]$} \\
\hline $\begin{array}{l}\text { Urine and plasma } \\
\text { oxalate }\end{array}$ & $\begin{array}{l}\text { HPLC/electrochemica } \\
\text { detection }\end{array}$ & $\begin{array}{l}\text { Plasma: } \mathrm{SAX} \text { cartridge } \\
\text { Urine: acidified urine passed through } \\
\mathrm{C}_{18} \text { column } \\
\text { Column conditioning solution: } \\
\mathrm{MeOH} / \text { water }(25: 75) \text { containing } 2 \\
\mathrm{mmol} / 1 \text { cetrimide }\end{array}$ & $\begin{array}{l}\text { Column: Spherisorb } \\
\text { ODS } 2,5 \mu \mathrm{m} 250 \times 4.6 \\
\mathrm{~mm} \\
\text { Mobile phase: } \\
\text { phosphate } \mathrm{pH} 7 / \mathrm{MeOH} \\
(90: 10) \\
\text { Detection } 1250 \mathrm{mV} \text {, } \\
\text { DC mode, time } \\
\text { constant } 5 \mathrm{~s}\end{array}$ & $\begin{array}{l}\text { Many compounds } \\
\text { (11) studied do not } \\
\text { offer interferences }\end{array}$ & $\begin{array}{l}\text { Plasma: } 0.6-2.8 \mu \mathrm{mol} / 1 \\
\text { Urine: } 109-497 \mu \mathrm{mol} / 24 \mathrm{~h}\end{array}$ & {$[104]$} \\
\hline $\begin{array}{l}\text { Urine and plasma } \\
\text { glycolate (GLY) } \\
\text { oxalate (OX) }\end{array}$ & $\begin{array}{l}\text { HPLC (ion } \\
\text { chromatography) }\end{array}$ & $\begin{array}{l}\text { Blood: ultrafiltration ( } \mathrm{MW}<25000 \\
\text { rel. mol. mass), cation-exchange resin, } \\
\text { addition of boric acid, centrifugation } \\
\text { Urine: acidified urine was cleaned } \\
\text { with } \mathrm{C}_{18} \text { cartridge and diluted }\end{array}$ & $\begin{array}{l}\text { Two different anion- } \\
\text { exchange columns: } \\
\text { for GLY (AS6A) and for } \\
\text { OX determination } \\
\text { (AS10) } \\
\text { Conductimetry detector }\end{array}$ & & $\begin{array}{l}\text { Plasma healthy controls } \\
\text { Men }(n=14) \\
\text { GLY: } 4.7 \pm 0.4 \\
\text { OX: } 2.0 \pm 0.2 \mu \mathrm{mol} / 1 \\
\text { Women }(n=25) \\
\text { GLY: } 4.4 \pm 0.3 \\
\text { OX: } 1.8 \pm 0.1 \mu \mathrm{mol} / 1\end{array}$ & {$[105]$} \\
\hline
\end{tabular}


Table 5. Continued

\begin{tabular}{|c|c|c|c|c|c|c|}
\hline & Technique & Sample preparation & Analysis & Artefacts & Normal ranges & Refs. \\
\hline $\begin{array}{l}\text { Urine and serum } \\
\text { oxalate }(\mathrm{OX}) \\
\text { phosphate (PHO) } \\
\text { sulphate (SUL) }\end{array}$ & $\begin{array}{l}\text { HPLC } \\
\text { Ion chromatography }\end{array}$ & $\begin{array}{l}\text { Acidified urine was diluted } 50 \text { (OX) } \\
\text { /400 fold (SUL, PHO) } \\
\text { Serum deproteinized by centrifugation }\end{array}$ & $\begin{array}{l}\text { AS4A anion-exchange } \\
\text { column } \\
\text { Suppressed } \\
\text { conductivity detector }\end{array}$ & & $\begin{array}{l}\text { Healthy individuals } \\
\text { OX: } 21.02 \pm 8.3 \mu \mathrm{mol} / 1 \\
\text { PHO: } 1.07 \pm 0.08 \mathrm{mmol} / 1 \\
\text { SUL: } 0.35 \pm 0.03 \mathrm{mmol} / 1\end{array}$ & [106] \\
\hline $\begin{array}{l}\text { Urine } \\
\text { oxalate }\end{array}$ & $\begin{array}{l}\text { HPLC/non-suppressed } \\
\text { ion chromatography }\end{array}$ & $\begin{array}{l}\text { Acidified urine was diluted with } \\
\text { benzidine hydrochloride to precipitate } \\
\text { sulphate. Supernatant passed through } \\
\mathrm{C}_{18} \text {-cartridge }\end{array}$ & $\begin{array}{l}\text { Anion-exchange } \\
\text { column } 140 \times 4.6 \mathrm{~mm}, 10 \\
\mu \mathrm{m} \\
\text { Mobile phase: borate- } \\
\text { gluconate buffer } \\
\text { Non-suppressed } \\
\text { conductivity detector }\end{array}$ & & Linear up to $1.0 \mathrm{~mol} / \mathrm{l}$ & [107] \\
\hline $\begin{array}{l}\text { Urine } \\
\text { glycolate } \\
\text { oxalate } \\
\text { citrate }\end{array}$ & HPLC & $\begin{array}{l}\text { Filter strip stored up to } 2 \text { weeks } \\
\text { Shaken in water, filtered ( } 10000 \\
\text { rel. mol. mass) }\end{array}$ & $\begin{array}{l}\text { IonPack AS11 } \\
\text { analytical column } \\
(4 \times 250 \mathrm{~mm}) \\
\text { Linear gradient }\end{array}$ & $\begin{array}{l}\text { Contaminative } \\
\text { fluoride may } \\
\text { interfere with } \\
\text { glycolate } \\
\text { Reanalysis with } \\
\text { System } 2 \text { is needed }\end{array}$ & $\begin{array}{l}\text { Control }(n=6) \\
\text { Liquid sample } \\
\text { GLY: } 42.5 \pm 2.07 \mathrm{mmol} / \mathrm{mol} \text { creatinine } \\
\text { OX } 23.2 \pm 1.16 \mathrm{mmol} / \mathrm{mol} \text { creatinine } \\
\text { CIT: } 272 \pm 6.7 \mathrm{mmol} / \mathrm{mol} \text { creatinine } \\
\text { Hyperoxaluria }(n=6) \\
\text { Liquid sample } \\
\text { GLY: } 297 \pm 5.5 \mathrm{mmol} / \mathrm{mol} \text { creatinine } \\
\text { OX: } 341 \pm 10.4 \mathrm{mmol} / \mathrm{mol} \text { creatinine } \\
\text { CIT: } 164 \pm 4.4 \mathrm{mmol} / \mathrm{mol} \text { creatinine }\end{array}$ & [49] \\
\hline $\begin{array}{l}\text { Urine } \\
\text { oxalate } \\
\text { citrate }\end{array}$ & $\begin{array}{l}\text { Capillary } \\
\text { electrophoresis }\end{array}$ & $\begin{array}{l}\text { Urine acidified with phosphoric acid, } \\
\text { was heated and diluted }\end{array}$ & $\begin{array}{l}\text { Polyimide-coated fused- } \\
\text { silica capillary } \\
\text { BGE: chromate and } \\
\text { TTAB } \\
\text { Constant current } \\
\text { Indirect UV detection } \\
\lambda 254 \mathrm{~nm}\end{array}$ & & $\begin{array}{l}\text { Urine: stone-forming patients } \\
(n=108) \text { OX: } 35.6 \pm 20.8 \mathrm{mg} / \text { day } \\
\text { Normal limit: }<40 \mathrm{mg} / \text { day } \\
\text { CIT: } 432 \pm 226 \mathrm{mg} / \text { day } \\
\text { Normal limit: }>292 \mathrm{mg} / \text { day }\end{array}$ & [133] \\
\hline $\begin{array}{l}\text { Urine } \\
\text { oxalate } \\
\text { citrate }\end{array}$ & $\begin{array}{l}\text { Capillary } \\
\text { electrophoresis }\end{array}$ & $\begin{array}{l}\text { Acidified urine was centrifuged and } \\
\text { diluted }\end{array}$ & $\begin{array}{l}\text { Polyacrylamide-coated } \\
\text { capillary } \\
\text { BGE: phosphate buffer } \\
\text { /MeOH }(90: 10) \\
\text { Negative voltage } \\
\text { Direct UV detection } \\
\lambda 200 \mathrm{~nm}\end{array}$ & & $\begin{array}{l}\text { Linear range: } \\
\text { CIT: } 200-1000 \mathrm{mg} / 1 \\
\text { OX: } 10-200 \mathrm{mg} / 1\end{array}$ & [118] \\
\hline $\begin{array}{l}\text { Urine } \\
\text { oxalate }\end{array}$ & Flow injection analysis & $\begin{array}{l}\text { Acidified urine was neutralised with } \\
\mathrm{NH}_{3} \text {. Precipitation of } \mathrm{OX} \text { with } \\
\text { calcium, dissolved with sulphuric acid } \\
4.5 \mathrm{~mol} / \mathrm{l}\end{array}$ & $\begin{array}{l}\text { Carrier stream: } 0.35 \\
\text { mol/1 } \mathrm{H}_{2} \mathrm{SO}_{4} \\
\text { Detection by } \\
\text { fluorimetry } \\
\lambda_{\mathrm{ex}} 350 \mathrm{~nm} ; \lambda_{\mathrm{em}} 480 \\
\mathrm{~nm} \\
\text { Fluorescent solution: } \\
\text { zirconyl chloride and } \\
\text { flavonol solution }\end{array}$ & & $\begin{array}{l}\text { Urine healthy controls } \\
(n=30) \\
\text { OX: } 0.24 \pm 0.11 \mathrm{mmol} / 24 \mathrm{~h} \\
\text { Oxalosis patients }(n=20) \\
\text { OX: } 0.33 \pm 0.12 \mathrm{mmol} / 24 \mathrm{~h} \\
\text { Linear up to } 0.36 \mathrm{mmol} / 1\end{array}$ & [120] \\
\hline $\begin{array}{l}\text { Urine } \\
\text { oxalate }\end{array}$ & $\begin{array}{l}\text { Atomic absorption and } \\
\text { UV-Vis absorption }\end{array}$ & $\begin{array}{l}\text { Urine } \mathrm{pH} \text { was adjusted with } \mathrm{HClO}_{4} \\
\text { Copper (II) oxinate in organic solvent } \\
\text { was shaken with the sample and } \\
\text { oxalate provoked organic layer } \\
\text { decolorisation }\end{array}$ & $\begin{array}{l}\text { AAS: lamp } \mathrm{Cu} \\
\text { Flame: air/acetylene } \\
\text { UVAS: } \lambda 395 / 415 \mathrm{~nm} \\
\text { Indirect determination } \\
\text { of oxalate }\end{array}$ & $\begin{array}{l}\text { The influence in } \\
\text { the determination } \\
\text { of } 20 \text { organic and } \\
15 \text { inorganic compounds } \\
\text { is studied }\end{array}$ & & [122] \\
\hline
\end{tabular}


glycoproteins was lower in stone formers than in control subjects. The largest-sized material from the stone formers was devoid of any activity on calcium oxalate precipitation. All of the remaining materials exerted inhibition on calcium oxalate precipitation. The inhibition rose progressively with the decreasing size of organic materials. Several works pointed to the inhibition of calcium oxalate crystal growth by macromolecules [51].

Nakagawa et al. [52] determined that the organic matrix of calcium oxalate kidney stones contains a glycoprotein inhibitor of calcium oxalate crystal growth, named nephrocalcin (14 000 rel. mol. mass) after dissociation in its monomeric forms) that resembles nephrocalcin present in the urine of patients with calcium oxalate stones and differs from nephrocalcin from the urine of normal people. Pulverized calcium oxalate renal stones were extracted with $0.05 M$ EDTA, pH 8.0; nephrocalcin eluted in five peaks using DEAE-cellulose column chromatography, and each peak was further resolved by Sephacryl S-200 column chromatography. Amino acid composition and surface properties of nephrocalcin isolated from kidney stones closely resembled those of nephrocalcins isolated from urine of stoneforming patients: they differed from normal in lacking $\gamma$-carboxyglutamic acid (GLA) residues, and a weakening of amphiphilicity.

Protein-bound urinary GLA was measured by HPLC with fluorescence detector after elimination of free GLA, alkaline hydrolysis and precolumn derivatization with $o$-phthalaldehyde and mercaptoethanol [53], a usual method for amino acid analysis. The authors found that protein-bound urinary GLA concentrations were similar in stone formers and controls. However, excretion rates of free and protein-bound GLA were higher in stone formers.

Fibronectin (230 000 rel. mol. mass) is a multifunctional $\alpha 2$-glycoprotein distributed throughout the extracellular matrix and body fluids. Recent studies have demonstrated that its secretion can be stimulated by calcium oxalate crystals, and this protein, which is excreted from the tubular cells, may inhibit calcium oxalate crystals' aggregation and attachment to cells. The fibronectin content was measured with the sandwich enzyme-linked immunosorbent assay method using a fibronectin kit. Briefly, samples, standards and negative controls were incubated with rabbit anti-human fibronectin polyclonal antibody. After they were washed, goat anti-rabbit immunoglobulin antibody conjugated with horseradish peroxidase was added and then $o$-phenylendiamine. Absorbance was measured at $492 \mathrm{~nm}$ [54].

Urinary prothrombin fragment 1 has been measured from calcium oxalate crystals matrix using DEAE-cellulose ion-exchange chromatography for purifying and then gel electrophoresis and Western blotting [55]. The authors say that there is increasing evidence that the protein is involved in the early stages of stone formation as an active participant in, and inhibitor of, calcium oxalate nucleation, growth and aggregation.

Tamm-Horsfall glycoproteins (THPs) from healthy probands and a majority of recurrent calcium oxalate renal stone formers revealed different physicochemical properties when analyzed using isoelectric focusing (IEF). The $\mathrm{p} I$ values of THPs from healthy probands are $\sim 3.5$ while THPs from recurrent renal stone formers have $\mathrm{p} I$ values of between 4.5 and 6 . The two groups of THPs exhibit completely different protein patterns. The differences in IEF analysis allow differentiation between THPs from healthy probands and recurrent calcium oxalate stone formers and may possibly be used as a simple diagnostic method for the recognition of recurrent calcium oxalate renal stone formers [56].

\subsubsection{Citric acid}

Citrate acts both through surface-controlled mechanisms to hamper crystal growth and aggregation and through the formation of stable soluble complexes with calcium [57]. Therefore, citrate determination has become an important tool in the assessment of urine supersaturation with respect to calcium oxalates and phosphates [58]. Following Parks and Coe, urine calcium and citrate are the two measurements that best distinguish calcium oxalate stone formers from normal [59].

The traditional enzymatic method for the determination of citrate uses citrate lyase, malate dehydrogenase, lactate dehydrogenase and NADH [60] and it is monitored spectrophotometrically or fluorimetrically [61-63].

Petrarulo et al. have proposed a new method for citrate determination that does not require the use of 
lactate dehydrogenase, malate dehydrogenase or $\mathrm{NADH}$ and is twice as sensitive as the traditional spectrophotometric method [58]. Methods which permit simultaneous measurement with oxalate and other compounds, will be discussed below.

Mean urinary citrate was $2.29 \mathrm{mmol}$ per $24 \mathrm{~h}$ in normal subjects. No significant difference was detected between levels in men and women. Urinary citrate excretion was significantly reduced in patients with renal calculi, intestinal resection or renal insufficiency but was unaltered in those with diabetes [64].

The identification and characterization of these inhibitors can be performed in vitro by a number of methods, most of which are complex and timeconsuming. Thus, Saso et al. developed a simple turbidimetric method based on the precipitation of calcium oxalate from a supersaturated solution. Using this approach, they determined that ionic strengths $>0.2$ and $\mathrm{pH}<5$ inhibited the precipitation of $\mathrm{CaOx}$. The first observation is of interest if one considers that the osmolarity of urine varies in the range of $50-1400 \mathrm{mmol} / \mathrm{kg}$, while the effect of $\mathrm{pH}$ is not usually seen in vivo because of the influence of other phenomena, such as the precipitation of uric acid [65].

\subsection{Analysis of promoters}

\subsubsection{Uric acid}

Uric acid is implicated in calcium oxalate kidney stone formation. Briefly, two hypothesis have been proposed: direct induction of calcium oxalate precipitation by uric acid, and uric acid as anti-inhibitor by binding urinary GAGS [66].

In relation to sample storage, high urinary uric acid concentration and low $\mathrm{pH}$ proved to play major roles in the decrease in urinary uric acid concentration after storage. In contrast, dilution of the urine samples before storage resulted in no significant change in urinary uric acid concentration. Based on these results, diluting urine before storage is recommend for determination of uric acid concentration and avoiding underestimation [67].

The classical method for uric analysis uses highly purified microbial uricase to quantitate uric acid by differential ultraviolet procedure [68].

A rapid and quantitative method for the simulta- neous measurement of uric acid, ascorbic acid, and related metabolites in biological fluids was developed. This method makes use of anion-exchange extraction columns to isolate the desired compounds from a wide range of biological fluids, and anionexchange HPLC with ultraviolet detection for their separation and measurement. By this procedure the contents of uric and ascorbic acids in human serum and urine were estimated. Furthermore, the oxidation of uric acid to allantoin and ascorbic acid to dehydroascorbic acid could be readily monitored [69].

A colorimetric method for the assay of uric acid in serum or urine, which utilises a Trinder chromogenic system modified by the inclusion of 2,4,6-tribromo3-hydroxybenzoic acid for oxidative coupling to $p$ aminophenazone was evaluated. Color development $\left(A_{\max }: 512 \mathrm{~nm}\right)$ is complete within $5 \mathrm{~min}$. The procedure involves pre-incubation with ascorbic acid oxidase and detergent to eliminate interference by ascorbic acid and to abolish turbidity due to lipemia. In human serum and urine the procedure correlates well with HPLC and the uricase $p$-aminophenazone method on the SMAC analyser. Within-run and between-run imprecisions of the enzymatic test were higher than for HPLC, but did not exceed 1.2\% (C.V.) and $2.5 \%$ (C.V.), respectively [70].

A direct, sensitive, and selective stopped-flow method for the fluorimetric determination of uric acid in serum and urine samples is described. The variation of fluorescence intensity during the reaction between uric acid and 1,1,3-tricyano-2-amino-1propene (triap) in the presence of hydrogen peroxide was monitored. The linear range of the proposed method was $0.08-3.00 \mathrm{mg}$ of uric acid per liter, and the detection limit was $0.03 \mathrm{mg} / 1$ [71].

A high-performance liquid chromatographic method was developed as an alternative to automated enzymatic analysis of uric acid in human urine preserved with thymol and/or thimerosal. Uric acid $\left(t_{\mathrm{R}}=10 \mathrm{~min}\right)$ and creatinine $\left(t_{\mathrm{R}}=5 \mathrm{~min}\right)$ were separated and quantified during isocratic elution $(0.025 \mathrm{M}$ acetate buffer, $\mathrm{pH}$ 4.5) from a $\mu$-Bondapak $\mathrm{C}_{18}$ column. The uric acid peak was identified chemically by incubating urine samples with uricase. The thymol/thimerosal peak appeared at $31 \mathrm{~min}$ during the washing step and did not interfere with the analysis. The high-performance liquid chromatographic method was validated for linearity, precision 
and accuracy, and the results were found to be excellent [72].

The principle of the signal amplification of a uric acid sensor based on dithiothreitol (DTT)-mediated intermediate regeneration of uricase was applied to a flow-injection system with an immobilized uricase reactor and a DTT-containing carrier. Highly sensitive detection for $\mathrm{n} M$ to $\mu M$ order of uric acid was achieved when $10 \mathrm{~m} M$ Tris-HCl buffer ( $\mathrm{pH} 10.0)$ containing $20 \mathrm{~m} M$ DTT was used as a carrier at 0.6 $\mathrm{ml} \mathrm{min}{ }^{-1}$ and $37^{\circ} \mathrm{C}$. The sensitivity of the uric acid was much improved over a batch method using a uricase membrane-coupling electrode, and the detection limit (peak current $\sim 8 \mathrm{nA}$ ) of uric acid was found to be down to $3 \times 10^{-10} M$ (amplification factor: more than 10000 ). This chemically amplified flow-system is very useful for the direct assay of uric acid in highly diluted biological fluids (urine and serum) without complicated pretreatment of the samples, because this sensor has the potential to detect trace amounts ( $\mathrm{n} M$ to $\mu M$ ) of uric acid in highly diluted body fluids in which the concentration of interfering constituents was decreased to negligible levels. Good correlation was observed between this system and conventional spectrophotometry. The immobilized uricase reactor could be re-used for at least 4 months of repeated analysis without loss of activity and was stable if stored at $4{ }^{\circ} \mathrm{C}$ in $10 \mathrm{mM}$ Tris-HCl buffer, pH 9.0 [73].

Capillary zone electrophoresis was used to perform a multi-analyte assay for markers of renal function in urine. This method tested for creatinine $(\mathrm{Cr})$, creatine $(\mathrm{Cn})$, uric acid (UA), and $p$-aminohippuric acid (PAH) levels. The limits of detection $(S / N=3)$ were found to be $5 \mu M$ for $\mathrm{Cr}, 0.75 \mu M$ for $\mathrm{Cn}$, and $1.5 \mu M$ for UA and PAH. Linear ranges were determined to be 5-500 $\mu M$ for $\mathrm{Cr}, 0.75-500$ $\mu M$ for $\mathrm{Cn}$, and $1.5-250 \mu M$ for $\mathrm{UA}$ and $\mathrm{PAH}$. These ranges included the expected concentrations of the markers in human urine after 50-fold dilution. This screening method proved to be a simple and fast way to perform a high throughput analysis for multiple renal function indicators [74].

Recently electrochemically anodized diamond film electrodes were used for selective detection of uric acid in the presence of high concentrations of ascorbic acid by differential pulse voltammetry and chronoamperometry. Human urine and serum were measured without preliminary treatment [75].

Conductivity is a non-linear function of electrolyte concentration in solutions and could be used as an indirect method. First morning urine specimens of 72 patients were obtained from all the patients and evaluated for osmolality, conductivity, $\mathrm{pH}$, specific gravity, protein, creatinine, urea, uric acid, glucose, sodium, potassium, chloride, inorganic phosphate and calcium levels. When the spectrum of conductivity values were evaluated separately in each group, $74 \%$ of the patients in group A and $33.9 \%$ of the patients in group B were determined to have a conductivity level of less than $7.338 \mathrm{mS} \mathrm{cm} \mathrm{cm}^{-1}$. In conclusion, urine conductivity has a positive relation with osmolality. In addition, while osmolality and specific gravity are affected by many non-electrolyte molecules, conductivity is only related to sodium and uric acid concentrations. In addition, urine osmolality and conductivity levels could be used to interpret the concentration of uncharged glucose molecules. These results suggest that conductivity could be used as a parameter in routine urinalysis [76].

2,8-Dihydroxyadenine lithiasis is a form of kidney stone previously mistaken for uric acid because of identical reactivity in non-specific tests used routinely. Diagnosis presents the greatest problem. Detection of the defect is possible from the presence of adenine and/or its 8-HA and 2,8-DHA metabolites in urine [77].

\subsubsection{Glycolate and glycerate}

Hyperoxaluria may be associated with increased urinary excretion of either glycolate in primary hyperoxaluria type I or L-glycerate in primary hyperoxaluria type II, but these metabolites are no longer adequate for accurate diagnosis, which requires either enzyme assessment or DNA analysis [78].

Increased urinary glycolate excretion was considered the most direct method for the diagnosis of type I primary hyperoxaluria in the absence of pyridoxine deficiency. However it is unlikely in adult life [79].

An enzymatic assay for the measurement of glycolate in urine and plasma has been described. Gycollic acid oxidase (glycollate: oxygen oxidoreductase, EC 1.1.3), extracted from spinach leaves, is used in the enzymatic oxidation of glycollate to 
produce glyoxylate and hydrogen peroxide. In the presence of peroxidase, the hydrogen peroxide oxidatively couples sulphonated 2,4-dichlorophenol and 4-aminophenazone to form a soluble purple quinoneimine dye. Interfering substances are removed from plasma by deproteinisation and from urine by adsorption onto activated charcoal before analysis. Glycollic acid oxidase also catalyses the oxidation of lactic acid which therefore has to be determined separately. The mean normal urinary glycollate for adults is $0.19 \mathrm{mmol} / 24 \mathrm{~h}$ with no difference between males and females [80].

A similar approach employs a continuous-flow system in a semiautomated procedure for the centrifugal analyzer and $(S)$-2-hydroxy-acid oxidase (EC 1.1.3.15; formerly called "glycolate oxidase"). The system with $(S)$-2-hydroxy-acid oxidase immobilized to the inner surface of nylon tubing is accurate, precise, and sensitive but unsuitable for routine use because, even immobilized, the oxidase is unstable and can only be used for 12 days [81].

An HPLC method described for glycolate is based upon the enzymatic conversion of glycolate to glyoxylate coupled with $\alpha$-keto acid derivatization with phenylhydrazine and the resulting phenylhydrazone separated by HPLC and detected at $324 \mathrm{~nm}$ [82], as shown in Fig. 1. A further modification of the method was also described [83], but the signal also includes glyoxylate concentration in samples, and although the authors say that it is negligible, it is an interference that could occasionally increase.

Routine organic acid analysis with diethyl ether extraction followed by gas chromatographic analysis failed to detect normal and increased concentrations of these diagnostic metabolites. Subsequent extraction of urine with tetrahydrofuran (THF), however, extracted $75 \%$ of added glycerate, $42 \%$ of added glycolate, and $75 \%$ of added ethylphosphonic acid (internal calibrator). THF extraction was analytically sensitive enough to allow determination of normal excretion of glycolate (14-72 $\mu \mathrm{g} / \mathrm{mg}$ creatinine) and glycerate $(0-5$ years, $12-177 \mu \mathrm{g} / \mathrm{mg}$ creatinine and $>5$ years, $19-115 \mu \mathrm{g} / \mathrm{mg}$ creatinine). Four of five patients with $\mathrm{PH}$ I and both patients with type II disease were correctly identified. Thus, THF extraction is a convenient adjunct to routine organic acid analysis and facilitates the detection of PH [84].

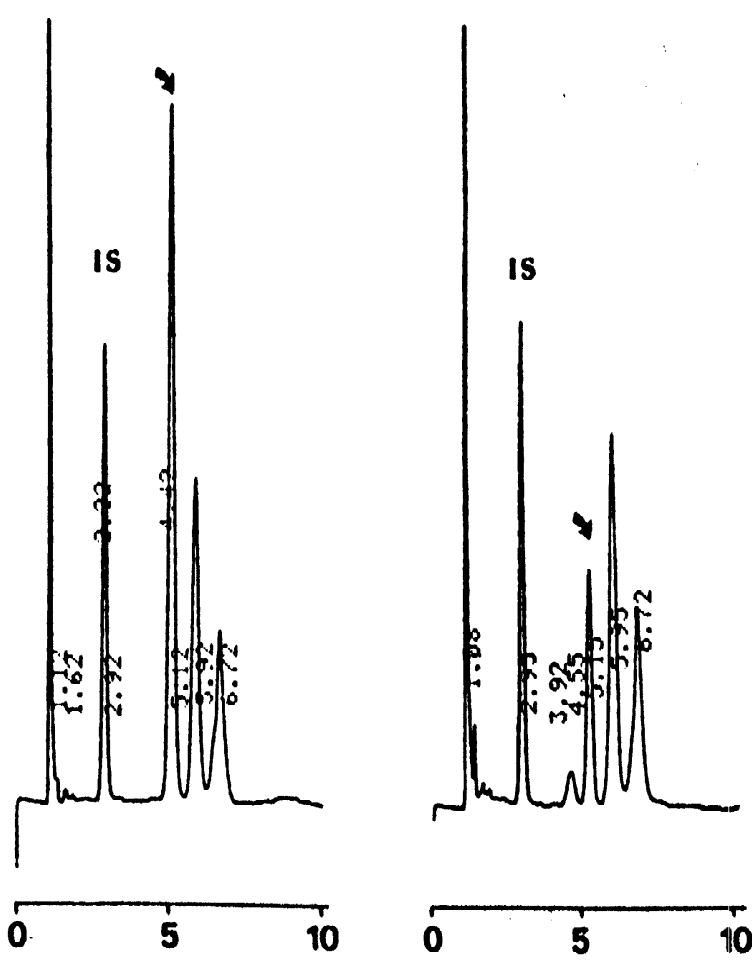

Fig. 1. Typical HPLC traces for the determination of glycolate. Left, glycolate standard, $800 \mu \mathrm{mol} / 1$ in water; right, urine sample. The arrows show the glyoxylate phenylhydrazone peak. Taken from Ref. [82]. No proper description of axes is available from the original paper.

A liquid chromatographic technique to determine L-glycerate in body fluids has also been described. The method is based on the derivatisation of the L-glycerate by incubation with lactate dehydrogenase and nicotinamide-adenine dinucleotide in the presence of phenylhydrazine. Oxidation of L-glycerate forms beta-hydroxypyruvate which is converted in turn into the related phenylhydrazone. The UV-absorbing derivative is determined using reversedphase HPLC. The sensitivity was $5 \mu \mathrm{mol} / 1$ and 50 $\mu l$ of sample were required. L-Glycerate concentrations in urine and plasma were less than $5 \mu \mathrm{mol} / 1$ in both normal individuals and patients with glycolic aciduria. In a patient with systemic oxalosis and normal plasma glycolate, plasma L-glyceric acid was $887 \mu \mathrm{mol} / 1$ [85].

Nevertheless, routine and reliable assays are still needed for other closely related organic acid anions such as glycolate and L-glycerate. 


\subsubsection{Oxalate}

A frequent affirmation in works related to lithiasis evaluation was that the measurement of urinary oxalate has been a major problem for clinical biochemists, despite the large number of methods published. The majority of the earlier methods for measuring oxalate required preliminary separation of oxalate from potential interfering substances. Invariably these separation procedures introduced errors due to incomplete precipitation, extraction or adsorption of oxalate and we will not insist on them. Nowadays, more reliable assays are available.

Factors affecting measurement of urinary oxalate such as ascorbic acid, $\mathrm{pH}$, phosphate, and the stability of urine stored at various temperatures were studied by Mazzachi et al. [86].

The presence of phosphate interfered with the precipitation of oxalate in those earlier methods which employed this separation technique. On the other hand, they showed that ascorbic acid is rapidly converted to oxalate at alkaline $\mathrm{pH}$. At $\mathrm{pH} 8$, increases in measured oxalate ranged from $20 \%$ at an ascorbic acid concentration of $1 \mathrm{mmol} / 1$ to more than $300 \%$ at $15 \mathrm{mmol} / \mathrm{l}$. Finally, as regards storage, after 1 month untreated collections were stable at $-70{ }^{\circ} \mathrm{C}$ and acidified collections at -20 and $-70{ }^{\circ} \mathrm{C}$. Urine specimens should be acidified within 2 days of collection if stored at $4{ }^{\circ} \mathrm{C}$ and immediately after collection if stored at room temperature, following this study.

Other authors [87] showed the oxalate generation at $\mathrm{pH} 7$ and above in amounts directly proportional to the ascorbate concentration and they propose disodium EDTA $10 \mathrm{mmol} / 1$ to inhibit such conversion. They also showed that other oxalate precursors: fructose, glucose, sucrose, lactulose, arabinose, glyoxylate, maltose, trehalose, and galactose did not generate oxalate at room temperature.

3.3.3.1. Enzymatic techniques. An oxalate oxidase continues to be the most popular approach for measuring urinary oxalate due to its specificity. Early problems were encountered [88], but the kit formulation was revised $[89,90]$. Preliminary separation of oxalate from its matrix is no longer necessary.

A modified enzyme-based colorimetric assay was developed with the oxalate oxidase immobilized in a nylon coil/peroxidase. Interferences were removed with activated charcoal. The color was developed by reaction with 3-methyl-2-benzothiazolinone and 3(dimethylamino)benzoic acid [91].

Oxalate may be measured by use of oxalate decarboxylase (OXDEC; EC 4.1.1.2) to produce formate, which is measured by a $\mathrm{NAD}^{+}$-dependent reaction catalysed by formate dehydrogenase. The method has been adapted to a Cobas Mira analyzer, which permits a fully automated assay [92].

The measurement of oxalate in urine was improved by employing barley oxalate oxidase immobilized on alkylamine glass beads affixed in a glass beaker. The minimum detection limit was 3.6 $\mathrm{mg} / \mathrm{l}$ urine. The recovery of added oxalate was $88.9 \pm 9.2 \%$. Within- and between-assay coefficients of variation (C.V.) were $<4.0$ and $<9.4 \%$, respectively. The urinary oxalate values were obtained by a commercial kit method and the present method showed a good correlation (0.999). The method is free from tedious handling of glass beads and chloride interference [93].

A continuous flow method is described for estimation of urinary oxalate, using oxalate oxidase (EC 1.2.3.4) and ascorbate oxidase (EC 1.10.3.3) immobilised on the inner surface of $O$-alkylated nylon tubes. Linearity, precision, oxalate recovery, freedom from interference by other urinary substances, accuracy, specificity, absence of interaction between samples and correlation with an established enzymic method were all excellent. The method has advantages over other methods in terms of speed, ease of use and cost. As the immobilised enzyme system was stable for 15 months the method is suitable for both research and routine use [94].

\subsubsection{Gas chromatography. Several GC methods} for oxalate or for organic acids measurement in urine were developed in the 1970s or before [95-97], but, nowadays, column technology has clearly improved.

The determination of oxalic acid by GC of the bis-2-chloroethyl ester of oxalic acid extracted into ethyl acetate/isopropyl ether (1:3, v/v) and detected by electron capture was studied by Moye et al. [98]. Validation parameters are adequate, but it is time consuming due to sample pretreatment. Trimethylsilyl derivative of oxalate in urine was also measured by GC and following the authors, it should be possible to determine glycolic acid too, but the 
method was not validated [99]. Fig. 2 shows the corresponding profile.

A GC-MS method with isotope dilution was proposed as reference method for determining urinary oxalate [100]. Comparisons were made with this method and four other existing procedures: a GC method, an HPLC method and two enzymatic assays. The results of the first two methods were in accordance with the GC-MS method. The enzymatic kits were less reliable.

The methods employed for quantitative metabolic profiling of urinary organic acids by GC-MS include oxalate, citrate, glyoxylate, and glycolate. This technique provides quantitative and structural information, but it requires relatively clean samples. The technique of solvent extraction was known to be unsatisfactory for many classes of organic acids. Extraction by DEAE Sephadex anion exchange removed copious amounts of sulfate and phosphate with organic acids. Preliminary barium precipitation

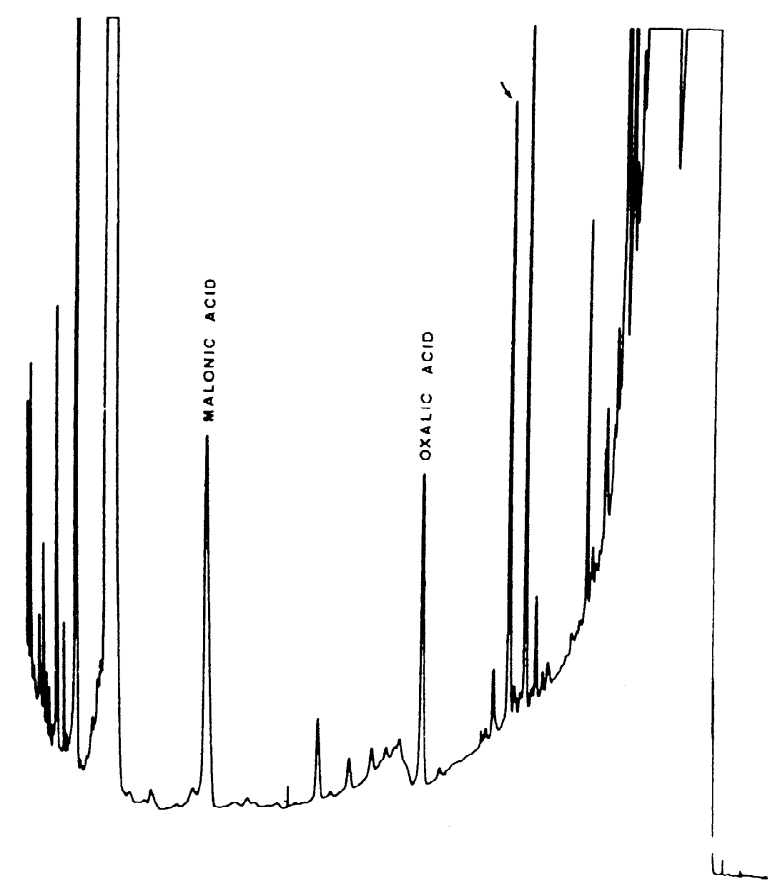

Fig. 2. Example of a GC analysis of oxalate in urine (normal sample). The arrow indicates the position of the glycollic acid peak. Taken from Ref. [99]. No proper description of axes is available from the original paper. was employed to eliminate these inorganic anions, but citrate can also precipitate.

Measuring the oxalate content and determining the bioavailability of dietary oxalate present some technical problems. As a result, some dietary information may be misleading. Surprisingly, beverages such as tea or beer, thought to increase urinary oxalate excretion, may actually protect against stone disease $[101,102]$. Finally, restriction of oxalate intake has been shown to reduce urinary oxalate levels, but not to prevent stone formation.

Intestinal hyperabsorption of oxalate has been studied by administering $\left[{ }^{13} \mathrm{C}_{2}\right]$ oxalic acid and measuring the labeled oxalate excreted in urine with GC-MS. Samples were extracted with ethyl acetate and derivatized with $N$-methyl-tert.-butyldimethylsilyl-trifluoro-acetamide [103].

\subsubsection{High-performance liquid chromatography.}

Acidified urine is pretreated by dilution with neutral phosphate buffer and passage through a $\mathrm{C}_{18}$ cartridge (1 $\mathrm{ml}$ Bond Elut). Treated samples are applied to an ion-paired chromatographic system with an Spherisorb ODS 2 column and oxalate detected electrochemically. A correlation coefficient of 0.97 for oxalate concentrations was obtained when compared with oxalate oxidase based assays. The same method can be applied in plasma [104].

High-performance ion chromatography (HPIC) has been employed for oxalate and glycolate urinary measurement in acidified samples after cleaning with $\mathrm{C}_{18}$ Sep Pak cartridges with two different procedures and two different anion-exchange columns (an AS10 column for oxalate and an AS6A column for glycolate) [105]. The same technique, HPIC with conductivity detector, was employed for the simultaneous determination of oxalate, glycolate, citrate, and sulfate. The system used an IonPack AS11 as analytical column and a gradient from water to $\mathrm{NaOH}$ as mobile phase [106]. The chromatogram obtained is shown in Fig. 3.

Another ion chromatographic method for determination of oxalate in urine has been described. Acidified urine was diluted 1:2 with $0.03 \mathrm{~mol} / 1$ benzidine hydrochloride in $0.3 \mathrm{~mol} / 1$ boric acid to precipitate sulphate. The supernatant was passed through a $\mathrm{C}_{18}$ cartridge and $100 \mu \mathrm{l}$ of eluant were injected into an ion chromatographic system. Oxalate 


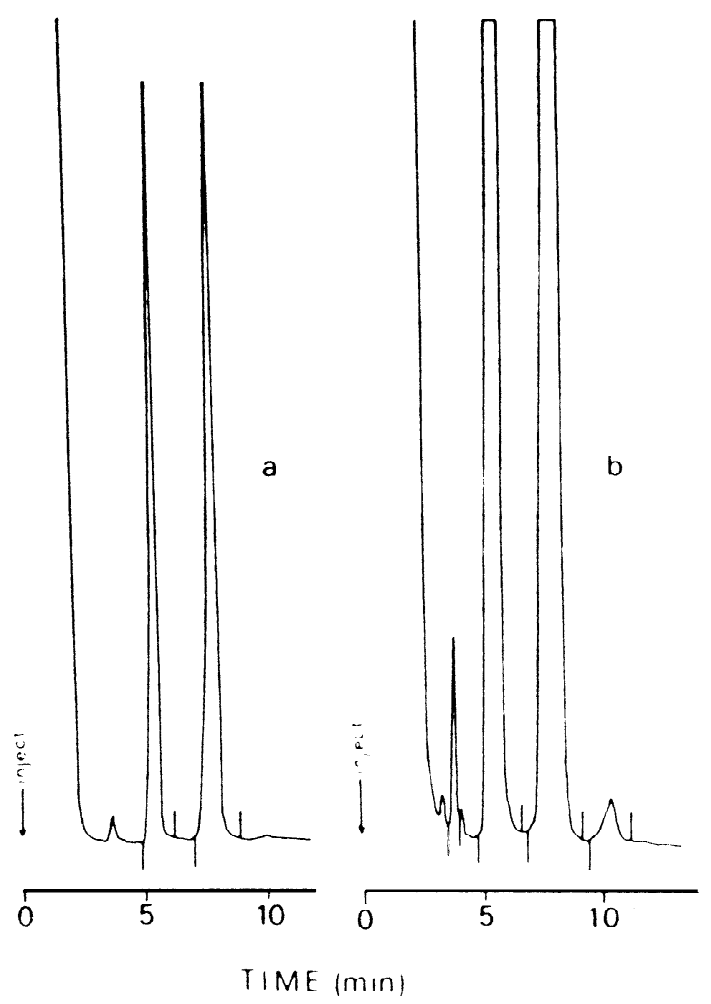

Fig. 3. Ion chromatography conductivity elution profile for 24-h human urine samples (a) 400-fold diluted and (b) 50-fold diluted containing oxalate (peak around $10 \mathrm{~min}$ ). Taken from Ref. [106]. No proper description of axes is available from the original paper.

was measured by non-suppressed conductivity detection. The detection limit for urinary oxalate was $0.05 \mathrm{mmol} / \mathrm{l}$. The recovery for spiked urine samples was $101.5 \%$ with a C.V. of $4.5 \%$. The results obtained by this method were statistically equivalent to an enzymatic assay and a different ion chromatographic method [107].

To overcome problems with interfering matrix anions, colorings, and macromolecules, an inline enzyme-reactor (ER) containing immobilised oxalate oxidase was used, which converts oxalate to hydrogen peroxide [108]. The method uses ion chromatography for the separation of anions. Hydrogen peroxide was analysed with high sensitivity by amperometric detection. The determination limit for the HPLC-ER method was $1.5 \mu \mathrm{mol} / 1$, and the mean recovery in urine was $102 \%$. The results of the new method were also statistically equivalent to those obtained by enzymatic kits.

3.3.3.4. Capillary electrophoresis (CE). Capillary electrophoresis has become a powerful analytical technique with an increasing impact in the clinical laboratory. The value of an analytical method is measured by how well it can be applied to "real world" samples. CE is proving to be especially suited for demanding analyses involving the separation of small organic molecules in complex sample matrices without pre-treatment.

Minimal sample volume and solvent consumption, coupled with high sensitivity, specificity, resolution, reproducibility, flexibility, and speed are key assets of CE.

Oxalic, together with another seven organic acids of clinical interest, was separated by CE by Willetts et al. [109], but quantitation was not evaluated. Moreover, oxalate was not detectable in the samples probably due to the noisy baseline caused by the surfactant. Indirect UV detection of short chain organic acids including oxalic and citric has been reported [110,111]. In the Holmes method urine samples need 100-fold dilution, which affects limits of detection, and this dilution may be variable depending on the sample concentrations. Indirect UV detection has also been employed to determine oxalate in amniotic fluid, but in spite of being amniotic fluid (a sample cleaner than urine), it needs previous clean up with $\mathrm{Ag}^{+}$resins to avoid chloride interference.

Fu et al. [112] determined oxalic acid in urine by co-electroosmotic capillary electrophoresis with amperometric detection. The paper shows research progress in this area, but it is not useful for routine work, because the detector is not commercially available.

Previous works in our laboratory [113-117] showed that the small organic molecules quoted above could be easily detected and measured by $\mathrm{CE}$ with direct UV absorbance.

We validated a method for direct measurement of oxalate and citrate and identification of glyoxylic and glyceric acids in urine [118]. The electropherogram including standards, an infant patient urine and the sample coinjected with the standards is shown in Fig. 4. There is no statistical difference in the results 


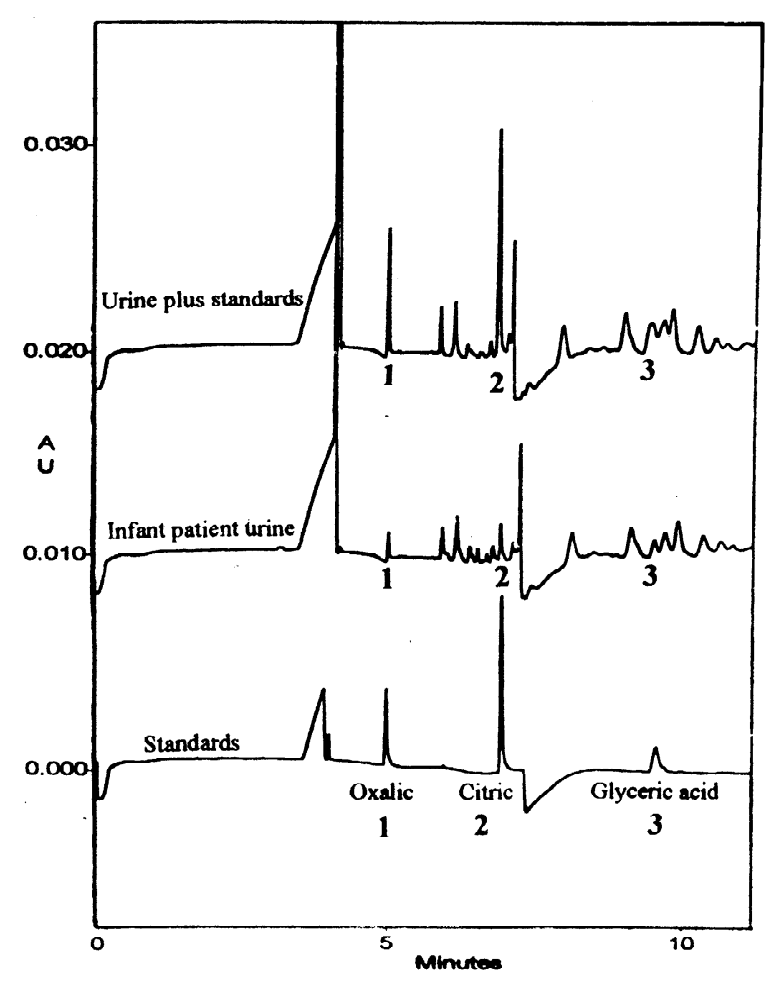

Fig. 4. Electropherograms of standards (oxalic, citric and glyceric acids), infant urine and this urine co-injected with the standards for identification. Taken from Ref. [118].

found with the proposed CE method as compared with the enzymatic methods and it can be considered accurate and reliable. Analysis time is under $10 \mathrm{~min}$. The simplicity of the whole process and the demonstrated good performance and high throughput make it highly recommended for routine clinical analysis.

3.3.3.5. Miscellaneous. An enzyme electrode for urine oxalate measurement has been produced using acrylamide gel-entrapped oxalate decarboxylase retained over a $\mathrm{CO}_{2}$ sensor. Urine required pre-treatment with EDTA, but oxalate extraction was not necessary [119].

A method is described for the determination of oxalate in urine using flow injection analysis and fluorimetry. Oxalate is precipitated with calcium chloride at $\mathrm{pH}$ 4.5, redissolved in $\mathrm{H}_{2} \mathrm{SO}_{4}$ and measured by flow injection analysis. The minimum detection limit is $6 \mu \mathrm{mol} / 1$ [120].

An extraction-spectrophotometric method is de- scribed for the determination of oxalate, based on the formation of a mixed ligand vanadium (V)-mandelohydroxamic acid-oxalate complex. The complex was extracted into a solution of trioctylmethylammonium chloride (Adogen 446) in toluene and the absorbance measured at $535 \mathrm{~nm}$ [121].

The indirect determination of oxalate has been described through copper (II). Copper (II), as oxinate in organic solution, is extracted by oxalate in aqueous solution. The extraction provokes organic layer decolorisation. The signal decrease in the organic layer is measured by UV-Vis absorption spectrometry and the copper concentration in the aqueous layer by atomic absorption spectrometry [122].

Although several problems related to selectivity, cost and handling still remain, the enzymatic methods are, nowadays, most popular for routine clinical analysis of oxalate, citrate and urate, the most generally established nephrolithiasis markers. Other techniques need to be employed for the measurement of less common inhibitors and promoters. Capillary electrophoresis could be the technique of choice to provide more simple and rapid analysis, almost without sample pre-treatment. The initial price of the equipment, which would be quickly compensated for by the low cost of reactives, and the need to learn a new technique in many cases, stops its development in routine analysis.

\section{Conclusion}

Enzymatic methods are more common in the clinical laboratory because they do not require personnel with special training or expensive equipment, but enzymes are expensive, the information obtained is limited and in some cases cross-reactions can interfere with the results. All the separation analytical methods (chromatography and capillary electrophoresis) present advantages and drawbacks. Chromatographies are more established techniques than capillary electrophoresis and therefore the equipment and trained personnel are more easily available. Nevertheless, the common drawback is the need for sample pre-treatment (derivatization, extraction or just clean-up) with the accompanying 
problems of loss of analytes, contamination, time consumption and so on.

In our opinion capillary electrophoresis, with direct measurement of oxalate and citrate in samples, is the easiest method to quantify these analytes, the method has proved to be reliable and the technique is daily becoming more established in the clinical laboratory (Table 5). Further efforts must be done to improve glycolate and glycerate measurement with $\mathrm{CE}$ to obtain all the required information.

\section{References}

[1] J. Crellin, R.A. Good, J.P. Mcgovern et al., In: The Aphorisms of Hippocrates (Section IV), Gryphon editions, Delran, NJ, 1982, p. 110.

[2] E.R. Kreutzer, V.W. Folkert, Curr. Opin. Nephrol. Hypertens. 2 (1993) 949.

[3] J.G. Collins, Department of Health and Human Services, Centers for Disease Control and Prevention/National Center for Health Statistics (NCHS), Maryland, USA, 1997, Vol. 10, p. 194.

[4] C.Y.C. Pak, Lancet 351 (1998) 1797.

[5] J.M. Soucie, M.J. Thun, R.J. Coates, W. McClellan, H. Austin, Kidney Int. 46 (1994) 893.

[6] G.C. Curhan, Miner. Electrolyte Metab. 23 (1997) 261.

[7] M. Marangella, C. Vitale, M. Petrarulo, C. Bagnis, M. Bruno, A. Ramello, J. Nephrol. 13 (Suppl. 3) (2000) S51.

[8] W.C. Robertson, M. Peacock, Urol. Int. 37 (1982) 394.

[9] C.Y.C. Pak, Am. J. Kidney Dis. 18 (1991) 624.

[10] N. Whalley, M.C. Martins, K.R.C. Wandy, A.M. Meyers, Br. J. Urol. Int. 84 (1999) 143.

[11] J.C. Lieske, F.G. Toback, Am. J. Physiol. 264 (1993) F800.

[12] G. Bihl, A. Meyers, Lancet 258 (2001) 651.

[13] E.M. Worcester, Semin. Nephrol. 16 (1996) 474.

[14] C.F. Verkoelen, B.G. Van Der Boom, J.C. Romijn, Kidney Int. 58 (2000) 1045.

[15] H.G. Teselius, H.F.A.M. Bek-Jensen et al., J. Urol. 154 (1995) 940.

[16] B. Hess, L. Zipperle, P. Jaeger, Am. J. Physiol. 265 (1993) F784.

[17] P.K. Grover, S.C. Dogra, B.P. Davidson, A.M.F. Stapelton, R.L. Ryall, Eur. J. Biochem. 267 (2000) 61.

[18] F. Atmani, B. Lacour, G. Stracker, P. Parvy, T. Bruecke, M. Daudon, Biochem. Biophys. Res. Commun. 191 (1993) 1158.

[19] R.M. Koka, E. Huang, J.C. Lieske, Am. J. Physiol. Renal Physiol. 278 (2000) 989.

[20] S.I. Goodman, F.E. Frerman, C.R. Scriver, A.L. Beaudey, W.S. Sly, D. Valle, 7th ed., The Metabolic and Molecular Basis of Inherited Disease, Vol. 1, McGraw-Hill, New York, 1995, p. 1451.
[21] F.L. Levy, B. Adams-Huet, C.Y. Pak, Am. J. Med. 98 (1995) 50.

[22] R.G. Bruce, L.C. Munch, A.D. Hoven, R.S. Jerauld, R. Greenburg, W.H. Porter et al., Urology 50 (1997) 513.

[23] T. Takemura, S. Hino, M. Ikeda, M. Okada, T. Igarashi, J. Inatomi, K. Yoshioka, Am. J. Kidney Dis. 37 (2001) 138.

[24] G. Rumsby, Mol. Urol. 4 (2000) 349.

[25] J.L. Porile, J.R. Asplin, J.H. Parks, Y. Nakagawa, F.L. Coe, J. Am. Soc. Nephrol. 7 (1996) 602.

[26] R.D. Monk, Semin. Nephrol. 16 (1996) 375.

[27] G. Kramer, H.C. Klingler, G.E. Steiner, Curr. Opin. Urol. 10 (2000) 35.

[28] E.O. Kajander, N. Ciftcioglu, Proc. Natl. Acad. Sci. USA 95 (1998) 8274.

[29] K. Sakhee, J.R. Poindexter, C.Y.C. Pak, J. Urol. 141 (1989) 819.

[30] R.W. Norman, Curr. Opin. Urol. 11 (2001) 347.

[31] T. Yagisawa, T. Hayashi, A. Yoshida et al., Eur. Urol. 38 (2000) 297.

[32] D.M. Wilson, J. Urol. 141 (1989) 770.

[33] C.A. Lehmann, G.L. McClure, I. Smolens, Clin. Chim. Acta 173 (1988) 107.

[34] P. Carmona, J. Bellanato, E. Escolar, Biospectroscopy 3 (1997) 331.

[35] C. Paluszkiewicz, M. Galka, W. Kwiatek, A. Parczewski, S. Walas, Biospectroscopy 3 (1997) 403.

[36] L. Estepa, M. Daudon, Biospectroscopy 3 (1997) 347.

[37] K. Sudlow, A. Woolf, Clin. Chim. Acta 203 (1991) 387.

[38] C.J. Farrington, M.L. Liddy, A.H. Chalmers, Am. J. Clin. Pathol 73 (1980) 96.

[39] E.W. Olcott, F.G. Sommer, Semin. Ultrasound CT MRI 20 (1999) 136.

[40] M.R. Mostafavi, R.D. Ernst, B. Saltzman, J. Urol. (Baltimore) 159 (1998) 673.

[41] M. Bak, J.K. Thomsen, H.J. Jakobsen, S.E. Petersen, T.E. Petersen, N.C. Nielsen, J. Urol. 164 (2000) 856.

[42] Anonymous, Consensus Conference, Prevention and Treatment of Kidney Stones, J. Am. Med. Assoc. 260 (1988) 977

[43] Information from Consensus Conference, Prevention and Treatment of Kidney Stones (web page), 1999, available at http://odp.od.nih.gov/consensus/cons/067/067_intro.htm.

[44] F.L. Coe, J.H. Parks, J.R. Asplin, N. Engl. J. Med. 327 (1992) 1141.

[45] G.C. Curhan, W.C. Willett, F.E. Speizer, M.J. Stampfer, Kidney Int. 59 (2001) 2290.

[46] J.H. Parks, M. Coward, F.L. Coe, Kidney Int. 51 (1997) 894.

[47] J.R. Asplin, J. Lingeman, R. Kahnoski, H. Mardis, J.H. Parks, F.L. Coe, J. Urol. 159 (1998) 664.

[48] N. Itami, K. Yasoshima, Y. Akutsu, K. Nonomura, Nephron 56 (1990) 337.

[49] N. Blau, A. Matasovic, A. Lukasiewicz-Wedlechowicz, C.W. Heizmann, E. Leumann, Clin. Chem. 44 (1998) 1554.

[50] T. Kitamura, J.E. Zerwekh, C.Y. Pak, Kidney Int. 21 (1982) 379.

[51] K.A. Edyvane, C.M. Hibberd, R.M. Harnett, V.R. Marshall, R.L. Ryall, Clin. Chim. Acta 167 (1987) 329.

[52] Y. Nakagawa, M. Ahmed, S.L. Hall, S. Deganello, F.L. Coe, J. Clin. Invest. 79 (1987) 1782. 
[53] C. Colette, A. Benmbarek, H. Boniface, C. Astre, N. ParesHerbute, L. Monnier, J. Guitter, Clin. Chim. Acta 204 (1991) 43.

[54] M. Tsujihata, O. Miyake, K. Yoshimura, K.-I. Kakimoto, S. Takahara, A. Okuyama, J. Urol. (Baltimore) 164 (2000) 1718.

[55] A.M. Stapleton, C.J. Dawson, P.K. Grover, A. Hohmann, R. Comacchio, V. Boswarva, Y. Tang, R.L. Ryall, Kidney Int. 49 (1996) 880.

[56] P. Schnierle, F. Herning, H. Seiler, Urol. Res. 24 (1996) 79.

[57] R.A. Ashby, R.J. Sleet, Clin. Chim. Acta 210 (1992) 157.

[58] M. Petrarulo, P. Facchini, E. Cerelli, M. Marangella, F. Linari, Clin. Chem. 41 (1995) 1518.

[59] J.H. Parks, F.L. Coe, Adv. Exp. Med. Biol. 208 (1986) 445.

[60] H. Moellering, W. Gruber, Anal. Biochem. 17 (1966) 369.

[61] T.T. Nielsen, Scand. J. Clin. Lab. Invest. 36 (1976) 513.

[62] S.G. Welshman, H. McCambridge, Clin. Chim. Acta 46 (1973) 243.

[63] A.J. Tomisek, E.M. Winkler, S. Natelson, Clin. Chem. 21 (1975) 730.

[64] M. Menon, C.J. Mahle, J. Urol. 129 (1983) 1158.

[65] L. Saso, G. Valentini, M.L. Casini, E. Mattei, C. Panzironi, B. Silvestrini, Urol. Int. 60 (1998) 47.

[66] A. Conte, P. Roca, C. Genestar, F. Grases, Nephron 52 (1989) 162.

[67] J. Yamakita, T. Yamamoto, Y. Moriwaki, S. Takahashi, Z. Tsutsumi, T. Hada, Ann. Clin. Biochem. 37 (2000) 355.

[68] P.H. Duncan, N. Gochman, T. Cooper, E. Smith, D. Bayse, Clin. Chem. 28 (1982) 284.

[69] L.L. Hatch, A. Sevanian, Anal. Biochem. 138 (1984) 324.

[70] H. Dubois, B. Delvoux, V. Ehrhardt, H. Greiling, J. Clin. Chem. Clin. Biochem. 27 (1989) 151.

[71] D. Pérez-Bendito, A. Gómez-Hens, M.C. Gutiérrez, S. Antón, Clin. Chem. 35 (1989) 230.

[72] Y.P.R.A. Chen, P.A. Whitson, J. Chromatogr. A 763 (1997) 187.

[73] Y. Hasebe, K. Nawa, S. Ujita, S. Uchiyama, Analyst 123 (1998) 1775.

[74] E.A. Clark, J.C. Fanguy, C.S. Henry, J. Pharm. Biomed. Anal. 25 (2001) 795.

[75] E. Popa, Y. Kubota, D.A. Tryk, A. Fujishima, Anal. Chem. 72 (2000) 1724.

[76] S. Kavukcu, M. Turkmen, A. Soylu, F. Kuralay, J. Pak. Med. Assoc. 48 (1998) 238.

[77] H.A. Simmonds, Clin. Chim. Acta 160 (1986) 103.

[78] P. Cochat, O. Basmaison, Arch. Dis. Child. 82 (2000) 470.

[79] E.R. Yendt, M. Cohanim, J. Urol. 141 (1989) 764.

[80] G.P. Kasidas, G.A. Rose, Clin. Chim. Acta 96 (1979) 25.

[81] R. Bais, J.M. Nairn, N. Potezny, A.M. Rofe, R.A. Conyers, A. Bar, Clin. Chem. 31 (1985) 710.

[82] M. Petrarulo, S. Pellegrino, O. Bianco, M. Marangella, F. Linari, E. Mentasti, J. Chromatogr. 465 (1989) 87.

[83] M. Petrarulo, O.C.D. Blanco, M. Maranguella, S. Pellegrino, F. Linari, J. Chromatogr. 532 (1990) 130.

[84] D.J. Dietzen, T.R. Wilhite, D.N. Kenagy, D.S. Milliner, C.H. Smith, M. Landt, Clin. Chem. 43 (1997) 1315.

[85] M. Petrarulo, M. Maranguella, D. Cosseddu, F. Linari, Clin. Chim. Acta 211 (1992) 143.
[86] B.C. Mazzachi, J.K. Teubner, R.L. Ryall, Clin. Chem. 30 (1984) 1339.

[87] A.H. Chalmers, D.M. Cowley, B.C. McWhinney, Clin. Chem. 31 (1985) 1703.

[88] Q.E. Crider, Clin. Chem. 31 (1985) 1080.

[89] I.M. Barlow, S.P. Harrison, Clin. Chem. 36 (1990) 1523.

[90] G.P. Kasidas, Nephrol. Dial. Transplant. 10 (1995) 8.

[91] D.M. Wilson, R.R. Liedtke, Clin. Chem. 37 (1991) 1229.

[92] A. Arnelli, D. Moraglio, Clin. Chem. 39 (1993) 1558.

[93] P. Chandran, M. Thakur, C.S. Pundir, J. Biotechnol. 85 (2001) 1 .

[94] K. Goldsack, R.F. Ginman, J.M. Wright, Med. Lab. Sci. 47 (1990) 73.

[95] C.E. Dalgliesh, E.C.H.M.C. Horning, K.L.Y.K. Knox, Biochem. J. 101 (1966) 792.

[96] J.A. Thompson, S.P. Markey, Anal. Chem. 47 (1975) 1313.

[97] D.E. Duggan, R.W. Walker, R.M. Noll, W.J.A. Van den Heuvel, Anal. Biochem. 94 (1979) 477.

[98] H.A. Moye, M.H. Malagodi, D.H. Clarke, C.J. Miles, Clin. Chim. Acta 114 (1981) 173.

[99] B.G. Wolthers, M. Hayer, Clin. Chim. Acta 120 (1982) 87.

[100] W. Koolstra, B.G. Wolthers, M. Hayer, H. Elzinga, Clin. Chim. Acta 170 (1987) 227.

[101] G.C. Curhan, W.C. Willett, E.B. Rimm, D. Spiegelman, M.J. Stampfer, Am. J. Epidemiol. 143 (1996) 240.

[102] G.C. Curhan, W.C. Willett, F.E. Speizer, M.J. Stampfer, Ann. Intern. Med. 128 (1998) 534.

[103] A. Sarkissian, A. Babloyan, N. Arikyants, A. Hesse, N. Blau, E. Leumann, Pediatr. Nephrol. 16 (2001) 728.

[104] I.D.R. Fry, B.J. Starkey, Ann. Clin. Biochem. 28 (1991) 581.

[105] L. Hagen, V.R. Walker, R.A.L. Sutton, Clin. Chem. 39 (1993) 134.

[106] L. Politi, R. Chiaraluce, V. Consalvi, N. Cerulli, R. Scandurra, Clin. Chim. Acta 184 (1989) 155.

[107] K. Pfeiffer, W. Berg, D. Bongartz, A. Hesse, Eur. J. Chem. Clin. Biochem. 35 (1997) 305.

[108] R. Hönow, D. Bongartz, A. Hesse, Clin. Chim. Acta 261 (1997) 131.

[109] M. Willetts, P. Clarkson, M. Cooke, Chromatographia 23 (1996) 671.

[110] H.O. Goodman, R.P. Holmes, D.G. Assimos, J. Urol. 153 (1995) 301.

[111] P. Goodyer, M. Boutros, R. Rozen, Exp. Nephrol. 8 (2000) 123.

[112] C. Fu, L. Wang, Y. Fang, Talanta 50 (1999) 953.

[113] A. García, C. Barbas, R. Aguilar, M. Castro, Clin. Chem. 44 (1998) 1905.

[114] C. Barbas, J.A. Lucas, F.J. Gutiérrez-Mañero, Phytochem. Anal. 10 (1999) 55.

[115] L. Saavedra, A. García, C. Barbas, J. Chromatogr. A 881 (2000) 395.

[116] L. Chafe, M.H. Gault, Clin. Nephrol. 41 (1994) 159.

[117] C. Spinelli, P. Berti, P. Miccoli, Minerva Chir. 49 (1994) 1343.

[118] A. Garcia, M. Muros, C. Barbas, J. Chromatogr. B Biomed. Sci. Appl. 755 (2001) 287. 
[119] P. Vadgama, W. Sheldon, J.M. Guy, A.K. Covington, M.F. Laker, Clin. Chim. Acta 142 (1984) 193.

[120] E. Gaetani, C.F. Laureri, M. Vitto, L. Borghi, G.F. Elia, A. Navarini, Clin. Chim. Acta 156 (1986) 71.

[121] F. Salinas, J.L. Martinez-Vidal, V. Gonzalez-Murcia, Analyst 114 (1989) 1685.

[122] J.A. Muñoz Leyva, M.P. Henández Artiga, M.M. Aragón Méndez, J.J. Quintana Pérez, Clin. Chim. Acta 195 (1990) 47.

[123] M. Kuwada, K. Katayama, Anal. Biochem. 131 (1983) 173.

[124] M. Kuwada, K. Katayama, J. Chromatogr. 308 (1984) 398.

[125] M. Petrarulo, M. Marangella, F. Linari, Clin. Chim. Acta 196 (1991) 17.
[126] M. Petrarulo, M. Marangella, D. Cosseddu, F. Linari, Clin. Chim. Acta 211 (1992) 143.

[127] E. Strauss, Clin. Chem. 33 (1987) 2301.

[128] A.H. Chalmers, D.M. Cowley, Clin. Chem. 30 (1984) 1891.

[129] P. Coyle, A.M. Rofe, F. Renfeng, Clin. Chem. 35 (1989) 1806.

[130] G.L. Mingen, M.M. Madappally, Clin. Chem. 35 (1989) 2330.

[131] H.A. Moye, M.H. Malagodi, D.H. Clarke, C.J. Miles, Clin. Chim. Acta 114 (1981) 173.

[132] W. Koolstra, B.G. Wolthers, M. Hayer, H.M. Rutgers, Clin. Chim. Acta 170 (1987) 237.

[133] R.P. Holmes, Clin. Chem. 41 (1995) 1297. 